\title{
Global-scale distribution of ozone in the remote troposphere from the ATom and HIPPO airborne field missions
}

\author{
Ilann Bourgeois ${ }^{1,2}$, Jeff Peischl ${ }^{1,2}$, Chelsea R. Thompson ${ }^{1,2}$, Kenneth C. Aikin ${ }^{1,2}$, Teresa Campos ${ }^{3}$, Hannah Clark ${ }^{4}$, \\ Róisín Commane $^{5}$, Bruce Daube ${ }^{6}$, Glenn W. Diskin ${ }^{7}$, James W. Elkins $^{8}$, Ru-Shan Gao ${ }^{2}$, Audrey Gaudel ${ }^{1,2}$, \\ Eric J. Hintsa ${ }^{1,8}$, Bryan J. Johnson ${ }^{8}$, Rigel Kivi ${ }^{9}$, Kathryn McKain ${ }^{1,8}$, Fred L. Moore ${ }^{1,8}$, David D. Parrish ${ }^{1,2}$, \\ Richard Querel $^{10}$, Eric Ray ${ }^{1,2}$, Ricardo Sánchez ${ }^{11}$, Colm Sweeney ${ }^{8}$, David W. Tarasick ${ }^{12}$, Anne M. Thompson ${ }^{13}$, \\ Valérie Thouret $^{14}$, Jacquelyn C. Witte ${ }^{3}$, Steve C. Wofsy ${ }^{6}$, and Thomas B. Ryerson ${ }^{2}$ \\ ${ }^{1}$ Cooperative Institute for Research in Environmental Sciences, University of Colorado Boulder, \\ Boulder, CO, USA \\ ${ }^{2}$ NOAA Chemical Science Laboratory, Boulder, CO, USA \\ ${ }^{3}$ National Center for Atmospheric Research, Boulder, CO, USA \\ ${ }^{4}$ IAGOS-AISBL, Brussels, Belgium \\ ${ }^{5}$ Department of Earth and Environmental Sciences, Lamont-Doherty Earth Observatory of Columbia University, \\ New York, NY, USA \\ ${ }^{6}$ School of Engineering and Applied Sciences, Harvard University, Cambridge, MA, USA \\ ${ }^{7}$ NASA Langley Research Center, Hampton, VA, USA \\ ${ }^{8}$ NOAA Global Monitoring Laboratory, Boulder, CO, USA \\ ${ }^{9}$ Finnish Meteorological Institute, Space and Earth Observation Centre, Sodankylä, Finland \\ ${ }^{10}$ National Institute of Water \& Atmospheric Research (NIWA), Lauder, New Zealand \\ ${ }^{11}$ Servicio Meteorológico Nacional, Buenos Aires, Argentina \\ ${ }^{12}$ Experimental Studies Research Division, MSC/Environment and Climate Change Canada, \\ Downsview, Ontario, Canada \\ ${ }^{13}$ Earth Sciences Division, NASA Goddard Space Flight Center, Greenbelt, MD, USA \\ ${ }^{14}$ Laboratoire d'Aérologie, CNRS and Université Paul Sabatier, Université de Toulouse, Toulouse, France
}

Correspondence: Ilann Bourgeois (ilann.bourgeois@noaa.gov) and Jeff Peischl (jeff.peischl@noaa.gov)

Received: 1 April 2020 - Discussion started: 14 April 2020

Revised: 17 July 2020 - Accepted: 25 July 2020 - Published: 11 September 2020

\begin{abstract}
Ozone is a key constituent of the troposphere, where it drives photochemical processes, impacts air quality, and acts as a climate forcer. Large-scale in situ observations of ozone commensurate with the grid resolution of current Earth system models are necessary to validate model outputs and satellite retrievals. In this paper, we examine measurements from the Atmospheric Tomography (ATom; four deployments in 2016-2018) and the HIAPER Pole-to-Pole Observations (HIPPO; five deployments in 2009-2011) experiments, two global-scale airborne campaigns covering the Pacific and Atlantic basins.

ATom and HIPPO represent the first global-scale, vertically resolved measurements of $\mathrm{O}_{3}$ distributions throughout
\end{abstract}

the troposphere, with HIPPO sampling the atmosphere over the Pacific and ATom sampling both the Pacific and Atlantic. Given the relatively limited temporal resolution of these two campaigns, we first compare ATom and HIPPO ozone data to longer-term observational records to establish the representativeness of our dataset. We show that these two airborne campaigns captured on average $53 \%, 54 \%$, and $38 \%$ of the ozone variability in the marine boundary layer, free troposphere, and upper troposphere-lower stratosphere (UTLS), respectively, at nine well-established ozonesonde sites. Additionally, ATom captured the most frequent ozone concentrations measured by regular commercial aircraft flights in the northern Atlantic UTLS. We then use the repeated verti- 
cal profiles from these two campaigns to confirm and extend the existing knowledge of tropospheric ozone spatial and vertical distributions throughout the remote troposphere. We highlight a clear hemispheric gradient, with greater ozone in the Northern Hemisphere, consistent with greater precursor emissions and consistent with previous modeling and satellite studies. We also show that the ozone distribution below $8 \mathrm{~km}$ was similar in the extra-tropics of the Atlantic and Pacific basins, likely due to zonal circulation patterns. However, twice as much ozone was found in the tropical Atlantic as in the tropical Pacific, due to well-documented dynamical patterns transporting continental air masses over the Atlantic. Finally, we show that the seasonal variability of tropospheric ozone over the Pacific and the Atlantic basins is driven yearround by transported continental plumes and photochemistry, and the vertical distribution is driven by photochemistry and mixing with stratospheric air. This new dataset provides additional constraints for global climate and chemistry models to improve our understanding of both ozone production and loss processes in remote regions, as well as the influence of anthropogenic emissions on baseline ozone.

\section{Introduction}

Tropospheric ozone $\left(\mathrm{O}_{3}\right)$ plays a major role in local, regional, and global air quality and significantly influences Earth's radiative budget (IPCC, 2013; Shindell et al., 2012). In addition, $\mathrm{O}_{3}$ drives tropospheric photochemical processes by controlling hydroxyl radical $(\mathrm{OH})$ abundance, which subsequently controls the lifetime of other pollutants including volatile organic compounds (VOCs), methane, and some stratospheric ozone-depleting substances (Crutzen, 1974; Levy, 1971). Sources of $\mathrm{O}_{3}$ to the troposphere include downward transport from the stratosphere (Junge, 1962) and photochemical production from precursors such as carbon monoxide $(\mathrm{CO})$, methane $\left(\mathrm{CH}_{4}\right)$, and VOCs in the presence of nitrogen oxides $\left(\mathrm{NO}_{x}\right)$ from natural or anthropogenic sources (Monks et al., 2009). Tropospheric $\mathrm{O}_{3}$ sinks include photodissociation, chemical reactions, and dry deposition. Owing to its relatively long lifetime $(\sim 23 \mathrm{~d}$ in the troposphere; Young et al., 2013), $\mathrm{O}_{3}$ can be transported across hemispheric scales. Thus, $\mathrm{O}_{3}$ mixing ratios over a region depend not only on local and regional sources and sinks but also on long-range transport. Further, the uneven density of $\mathrm{O}_{3}$ monitoring locations around the globe leads to significant sampling gaps, especially near developing nations and away from land (Gaudel et al., 2018). The troposphere over the remote oceans is among the least-sampled regions, despite hosting $60 \%-70 \%$ of the global tropospheric $\mathrm{O}_{3}$ burden (Holmes et al., 2013).

Since the early 1980s, several aircraft campaigns have addressed this paucity of remote observations, most notably under the umbrella of the Global Tropospheric Exper- iment (GTE), a major component of the National Aeronautics and Space Administration (NASA) Tropospheric Chemistry Program (https://www-gte.larc.nasa.gov, last access: 9 April 2020). Airborne campaigns have targeted both the Pacific and Atlantic oceans, providing novel characterization of $\mathrm{O}_{3}$ sources, distribution, and photochemistry in the marine troposphere (Browell et al., 1996a; Davis et al., 1996; Jacob et al., 1996; Pan et al., 2015; Schultz et al., 1999; Singh et al., 1996c) and the low-O $\mathrm{O}_{3}$ tropical Pacific pool (Singh et al., 1996b); the pervasive role of continental outflow on $\mathrm{O}_{3}$ production (Bey et al., 2001; Crawford et al., 1997; Heald et al., 2003; Kondo et al., 2004; Martin et al., 2002; Zhang et al., 2008); and the marked influence of African and South American biomass burning on $\mathrm{O}_{3}$ production in the Southern Hemisphere (Browell et al., 1996b; Fenn et al., 1999; Mauzerall et al., 1998; Singh et al., 1996a; Thompson et al., 1996). Ozonesondes have been launched from remote sites for more than 3 decades in some places and have provided additional constraints on the sources and photochemical balance of tropospheric $\mathrm{O}_{3}$, including a deep understanding of the vertically resolved tropospheric $\mathrm{O}_{3}$ climatology in select locations (Derwent et al., 2016; Diab et al., 2004; Jensen et al., 2012; Kley et al., 1996; Liu et al., 2013; Logan, 1985; Logan and Kirchhoff, 1986; Newton et al., 2018; Oltmans et al., 2001; Parrish et al., 2016; Sauvage et al., 2006; Thompson et al., 2012). Spatially resolved $\mathrm{O}_{3}$ climatology has been provided from routine sampling by commercial aircraft, which has mostly been limited to the upper troposphere or over continental regions (Clark et al., 2015; Cohen et al., 2018; Logan et al., 2012; Petetin et al., 2016; Sauvage et al., 2006; Thouret et al., 1998; Zbinden et al., 2013), and by satellite observations (Edwards et al., 2003; Fishman et al., 1990, 1991; Hu et al., 2017; Thompson et al., 2017; Wespes et al., 2017; Ziemke et al., 2005, 2006, 2017), which have been somewhat tempered by large uncertainties (Tarasick et al., 2019b). Recent overview analyses depict the current understanding of global tropospheric $\mathrm{O}_{3}$ sources, distribution, and photochemical balance and underscore the insufficiency of observations in the remote free troposphere (Cooper et al., 2014; Gaudel et al., 2018; Tarasick et al., 2019b) necessary to improve the current representation of tropospheric $\mathrm{O}_{3}$ in global chemical models (Young et al., 2018). The spatial and temporal representativeness of $\mathrm{O}_{3}$ observations is currently the biggest source of uncertainty when inferring $\mathrm{O}_{3}$ climatology in the free troposphere, even in regions where observation are abundant but not ideally distributed (Lin et al., 2015b; Tarasick et al., 2019b). Most studies reporting the global $\mathrm{O}_{3}$ distribution use satellite observations (Edwards et al., 2003; Fishman et al., 1990, 1991; Thompson et al., 2017; Wespes et al., 2017; Ziemke et al., 2005, 2006, 2017), modeling analyses (Hu et al., 2017), or observations spatially expanded using back trajectory calculations (e.g., Liu et al., 2013; Tarasick et al., 2010). While useful, these studies come with somewhat large uncertainties, as recently noted by reports from the Tropospheric Ozone Assessment Report (TOAR), and 


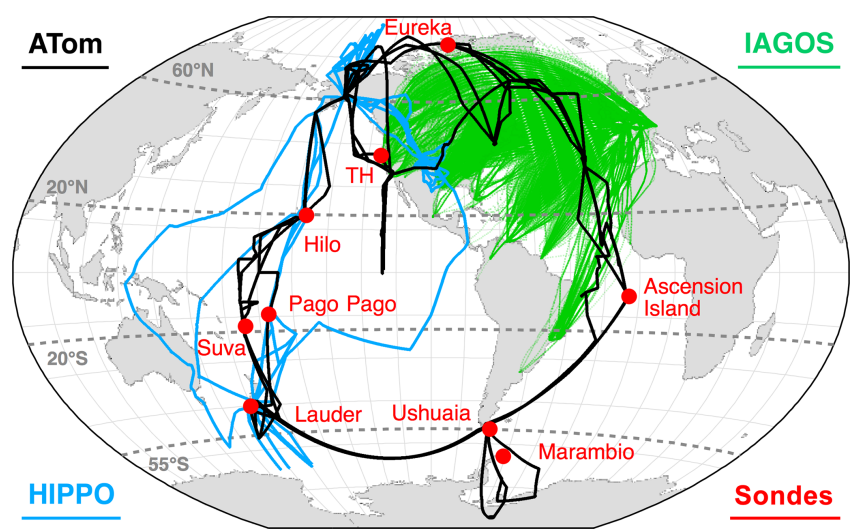

Figure 1. The location and flight tracks of all $\mathrm{O}_{3}$ monitoring platforms used in this work are illustrated using different markers and colors. The ATom flight track is in black, the HIPPO flight track is in blue, IAGOS flight paths are in green, and the ozonesonde launching sites are indicated by the red markers. The dotted gray lines define the latitudinal bands over which individual ATom and HIPPO profiles were averaged to derive a regional $\mathrm{O}_{3}$ distribution: the tropics $\left(20^{\circ} \mathrm{S}-20^{\circ} \mathrm{N}\right)$, the midlatitudes $\left(55-20^{\circ} \mathrm{S}, 20-60^{\circ} \mathrm{N}\right)$, and the high latitudes $\left(90-55^{\circ} \mathrm{S}, 60-90^{\circ} \mathrm{N}\right)$. Only data from remote oceanic flight segments of ATom and HIPPO missions were used in this work.

thus require additional in situ observations to be used as a validation benchmark (Tarasick et al., 2019b; Young et al., 2018).

The Atmospheric Tomography (ATom, https://espo.nasa. gov/atom, last access: 9 April 2020) mission was a NASA Earth Venture airborne field project to address the sparseness of atmospheric observations over remote ocean regions by systematically sampling the troposphere over the Pacific and Atlantic basins along a global-scale circuit (Fig. 1). ATom deployed an extensive payload on the NASA DC-8 aircraft, measuring a wide range of chemical, microphysi$\mathrm{cal}$, and meteorological parameters in repeated vertical profiles from $0.2 \mathrm{~km}$ to over $13 \mathrm{~km}$ in altitude, from the Arctic to the Antarctic over the Pacific and Atlantic oceans, in four separate seasons from 2016 to 2018. ATom built on a previous study, the HIAPER Pole-to-Pole Observations (HIPPO, https://www.eol.ucar.edu/field_projects/hippo, last access: 9 April 2020) mission. The goal of HIPPO was to measure atmospheric distributions of important greenhouse gases and reactive species over the Pacific Ocean, from the surface to the tropopause, five times during different seasons from 2009 to 2011. Together, ATom and HIPPO provide recent and comprehensive information about the altitudinal, latitudinal, and seasonal composition of the remote troposphere over the Pacific, and ATom also provides this information over the Atlantic. In addition, ATom and HIPPO sampling strategies were designed to deliver an objective climatology of key species to enable the modeling of the air parcel reactivity of the remote troposphere (Prather et al., 2017).
Here we use existing ozonesonde and commercial aircraft observations of $\mathrm{O}_{3}$ at selected locations along the ATom and HIPPO circuits to provide a climatological context for the altitudinal, latitudinal, and seasonal distributions of $\mathrm{O}_{3}$ derived from the systematic airborne in situ "snapshots". Long-term $\mathrm{O}_{3}$ observations are obtained from decades of ozonesonde vertical profiles (e.g., Oltmans et al., 2013; Thompson et al., 2017) and from $\sim 60000$ flights using the In-service Aircraft for a Global Observing System (IAGOS) infrastructure (Petzold et al., 2015; http://www.iagos.org, last access: 9 April 2020). Ozonesondes have typically been launched weekly for 2 decades or more, depending on the site, and have sampled a wide range of air masses across the globe, from $\mathrm{O}_{3}$-poor remote surface locations to the $\mathrm{O}_{3}$-rich stratosphere. IAGOS commercial aircraft have provided daily measurements in the upper troposphere and lower stratosphere (UTLS) for the past 25 years, especially over the northern midlatitudes between America and Europe. Combined, the ozonesonde and IAGOS datasets offer robust measurement-based climatologies that quantify the full expected range of atmospheric $\mathrm{O}_{3}$ variability with altitude and season.

The in situ data from temporally limited intensive field studies can be placed in context by comparing them with long-term ozonesonde and commercial aircraft monitoring data. Evaluating the representativeness of in situ observations from airborne campaigns by comparing them to longer-term observational records is a critical exercise never before done at such a global scale. We show that ATom and HIPPO measurements capture the spatial and, in some cases, temporal dependence of $\mathrm{O}_{3}$ in the remote atmosphere, thereby highlighting the usefulness of airborne observations to fill in the gaps of established but limited $\mathrm{O}_{3}$ climatologies and other similarly long-lived species. Then, we use the geographically extensive ATom and HIPPO vertical profile data to establish a more complete measurement-based benchmark for $\mathrm{O}_{3}$ abundance and distribution in the remote marine atmosphere.

\section{Measurements}

\subsection{ATom}

The four ATom circuits occurred in July-August 2016 (ATom-1), January-February 2017 (ATom-2), SeptemberOctober 2017 (ATom-3), and April-May 2018 (ATom-4); thus, they spanned all four seasons in both hemispheres over a 2-year timeframe (Table S1 in the Supplement). In total, the mission consisted of 48 science flights and 548 vertical profiles distributed nearly equally along the global circuit. All four deployments completed roughly the same loop, starting and ending in Palmdale, California, USA (Fig. 1). A notable addition during ATom-3 and ATom-4 were out-andback flights from Punta Arenas, Chile, to sample the Antarctic troposphere and UTLS. 
$\mathrm{O}_{3}$ was measured using the National Oceanic and Atmospheric Administration (NOAA) nitrogen oxides and ozone $\left(\mathrm{NO}_{y} \mathrm{O}_{3}\right)$ instrument. The $\mathrm{O}_{3}$ channel of the $\mathrm{NO}_{y} \mathrm{O}_{3}$ instrument is based on the gas-phase chemiluminescence (CL) detection of ambient $\mathrm{O}_{3}$ with pure $\mathrm{NO}$ added as a reagent gas (Ridley et al., 1992; Stedman et al., 1972). Ambient air is continuously sampled from a pressure-building ducted aircraft inlet into the $\mathrm{NO}_{y} \mathrm{O}_{3}$ instrument at a typical flow rate of $1025.0 \pm 0.2$ standard cubic centimeters per minute $(\mathrm{sccm})$ in flight. Pure NO reagent gas flow delivered at $3.450 \pm$ $0.006 \mathrm{sccm}$ is mixed with sampled air in a pressure $(8.00 \pm$ 0.08 Torr $)$ and temperature $\left(24.96 \pm 0.01^{\circ} \mathrm{C}\right)$ controlled reaction vessel. NO-induced CL is detected with a dry-icecooled, red-sensitive photomultiplier tube and the amplified digitized signal is recorded using an $80 \mathrm{MHz}$ counter; pulse coincidence corrections at high count rates were applied, but they are negligible for the data presented in this work. The instrument sensitivity for measuring $\mathrm{O}_{3}$ under these conditions is $3150 \pm 80$ counts per second per part per billion by volume (ppbv) averaged over the entire ATom circuit. CL detector calibrations were routinely performed both on the ground and during flight by standard addition of $\mathrm{O}_{3}$ produced by irradiating ultrapure air with $185 \mathrm{~nm} \mathrm{UV}$ light and were independently measured using UV optical absorption at $254 \mathrm{~nm}$. $\mathrm{All} \mathrm{O}_{3}$ measurements were taken at a temporal resolution of $10 \mathrm{~Hz}$, averaged to $1 \mathrm{~Hz}$, and corrected for the dependence of instrument sensitivity on ambient water vapor content (Ridley et al., 1992). Under these conditions the total estimated $1 \mathrm{~Hz}$ uncertainty at sea level is $\pm(0.015 \mathrm{ppbv}+2 \%)$.

A commercial dual-beam photometer (2B Technologies Model 211) based on UV optical absorption at $254 \mathrm{~nm}$ also measured $\mathrm{O}_{3}$ on ATom, with an estimated uncertainty of \pm $(1.5 \mathrm{ppbv}+1 \%)$ at a $2 \mathrm{~s}$ sampling resolution. Comparison of the $2 \mathrm{~B}$ absorption instrument $\mathrm{O}_{3}$ data to the $\mathrm{NO}_{y} \mathrm{O}_{3} \mathrm{CL}$ instrument $\mathrm{O}_{3}$ data agreed to within combined instrumental uncertainties, lending additional confidence to the $\mathrm{NO}_{y} \mathrm{O}_{3} \mathrm{CL}$ instrument calibration. For the ATom project, we use $\mathrm{NO}_{y} \mathrm{O}_{3}$ instrument $\mathrm{O}_{3}$ data in the following analyses.

Data from two CO measurements were combined in this analysis. The Harvard quantum cascade laser spectrometer (QCLS) instrument used a pulsed quantum cascade laser tuned at $\sim 2160 \mathrm{~cm}^{-1}$ to measure the absorption of $\mathrm{CO}$ through an astigmatic multi-pass sample cell with $76 \mathrm{~m}$ path length and detection using a liquid-nitrogen-cooled $\mathrm{HgCdTe}$ detector (Santoni et al., 2014). In-flight calibrations were conducted with gases traceable to the NOAA World Meteorological Organization (WMO) X2014A scale, and the QCLS observations have an accuracy and precision of 3.5 and $0.15 \mathrm{ppb}$ for $1 \mathrm{~Hz}$ data, respectively. $\mathrm{CO}$ was also measured by the NOAA cavity ring-down spectrometer (CRDS, Picarro, Inc., model G2401-m; Karion et al., 2013) in the $1.57 \mu \mathrm{m}$ region with a total uncertainty of $5.0 \mathrm{ppbv}$ for $1 \mathrm{~Hz}$ data. The NOAA Picarro data were also reported on the World Meteorological Organization (WMO) X2014A scale. The combined $\mathrm{CO}$ data $(\mathrm{CO}-\mathrm{X})$ used here correspond to the
QCLS data, with the Picarro measurement used to fill calibration gaps in the QCLS time series.

Water $\left(\mathrm{H}_{2} \mathrm{O}\right)$ vapor was measured using the NASA Langley Diode Laser Hygrometer (DLH), an open-path infrared absorption spectrometer that uses a laser locked to a water vapor absorption feature at $\sim 1.395 \mu \mathrm{m}$. Raw data are processed at the instrument's native $\sim 100 \mathrm{~Hz}$ acquisition rate and averaged to $1 \mathrm{~Hz}$ with an overall measurement accuracy within $5 \%$.

\subsection{HIPPO}

The HIPPO mission consisted of five seasonal deployments over the Pacific Basin between 2009 and 2011, from the North Pole to the coastal waters of Antarctica (Wofsy, 2011). HIPPO deployments consisted of two transects, southbound and northbound, and occurred in January 2009 (HIPPO-1), October-November 2009 (HIPPO-2), March-April 2010 (HIPPO-3), June-July 2011 (HIPPO-4), and August-September 2011 (HIPPO-5). The platform used was the NSF Gulfstream V (GV) aircraft. More details can be found in Table $\mathrm{S} 1$.

A NOAA custom-built dual-beam photometer based on UV optical absorption at $254 \mathrm{~nm}$ was used to measure $\mathrm{O}_{3}$ (Proffitt and McLaughlin, 1983). The uncertainty of the $1 \mathrm{~Hz}$ $\mathrm{O}_{3}$ data is estimated to be $\pm(1 \mathrm{ppbv}+5 \%)$ for $1 \mathrm{~Hz}$ data. A commercial dual-beam $\mathrm{O}_{3}$ photometer (2B Technologies Model 205) based on UV optical absorption at $254 \mathrm{~nm}$ was also included in the HIPPO payload. Comparison of the $2 \mathrm{~B}$ $\mathrm{O}_{3}$ data to the NOAA $\mathrm{O}_{3}$ data showed general agreement within combined instrument uncertainties on level flight legs. For the HIPPO project, we use $\mathrm{NOAA} \mathrm{O}_{3}$ data in the following analyses.

Data from two CO measurements were combined in this analysis. The QCLS instrument was the same instrument as that used during ATom and is described in Sect. 2.1. CO was also measured by an Aero-Laser AL5002 instrument using vacuum UV resonance fluorescence (in the 170-200 nm range) with an uncertainty of $\pm(2 \mathrm{ppbv}+3 \%)$ at a $2 \mathrm{~s}$ sampling resolution. The combined $\mathrm{CO}$ data $(\mathrm{CO}-\mathrm{X})$ used here correspond to the QCLS data, with the Aero-Laser measurement used to fill calibration gaps in the QCLS time series.

\subsection{IAGOS}

IAGOS is a European Research Infrastructure that provides airborne in situ chemical, aerosol, and meteorological measurements using commercial aircraft (Petzold et al., 2015). The IAGOS Research Infrastructure includes data from both the CARIBIC (Civil Aircraft for the Regular Investigation of the atmosphere Based on an Instrument Container; Brenninkmeijer et al., 2007) and MOZAIC (Measurements of OZone and water vapor by Airbus In-service airCraft; Marenco et al., 1998) programs, providing measurements from $\sim 60000$ flights since 1994 . We note the relative lack 
of IAGOS data over the Pacific compared with the Atlantic (shorter temporal record, lower flight frequency, and fewer flights with concomitant $\mathrm{O}_{3}$ and $\mathrm{CO}$ measurements) and, therefore, limited the comparison to the Atlantic. Because commercial aircraft cruise altitudes over the ocean are predominantly between 9 and $12 \mathrm{~km}$, the comparison between ATom and IAGOS is further limited to the UTLS (Fig. 1). More details are shown in Table S1.

Identical dual-beam UV absorption photometers measured $\mathrm{O}_{3}$ aboard the IAGOS flights. An instrument comparison demonstrated that the photometers (standard Model 49, Thermo Scientific, modified for aircraft use) showed good consistency in measuring $\mathrm{O}_{3}$ (Nédélec et al., 2015). The associated uncertainty is $\pm(2 \mathrm{ppbv}+2 \%)$ at a 4 s sampling resolution (Thouret et al., 1998).

$\mathrm{CO}$ measurements were made using infrared absorption photometers (standard Model 48 Trace Level, Thermo Scientific, modified for aircraft use) with an uncertainty of \pm $(5 \mathrm{ppbv}+5 \%)$ at a $30 \mathrm{~s}$ sampling resolution (Nédélec et al., 2003, 2015).

\subsection{Ozonesondes}

Ozonesondes have measured the vertical distribution of $\mathrm{O}_{3}$ in the atmosphere for decades, and they provide some of the longest tropospheric records that are commonly used to determine regional $\mathrm{O}_{3}$ trends (Gaudel et al., 2018; Leonard et al., 2017; Oltmans et al., 2001; Tarasick et al., 2019a; Thompson et al., 2017). Ozonesonde launching sites are operated by the NOAA Earth System Research Laboratory (ESRL) Global Monitoring Laboratory (GML), NASA Goddard's Southern Hemisphere Additional OZonesondes (SHADOZ) program, the New Zealand National Institute of Water \& Atmospheric Research (NIWA), the National Meteorological Center of Argentina in collaboration with the Finnish Meteorological Institute (FMI), or Environment and Climate Change Canada. A more detailed description of each ozonesonde site and the corresponding dataset can be found in Tables S1 and S2. All sites use electrochemical concentration cell (ECC) ozonesondes that rely on the potassium iodide electrochemical detection of $\mathrm{O}_{3}$ and that provide a vertical resolution of about $100 \mathrm{~m}$ (Komhyr, 1969). The associated uncertainty is usually $\pm(5 \%-10 \%)$ (Tarasick et al., 2019b; Thompson et al., 2019; Witte et al., 2018).

\subsection{Data analysis}

In this analysis, ATom flight tracks were divided into the Atlantic and Pacific basins and then further subdivided into five regions within those basins: the tropics and the northern and southern middle and high latitudes. Vertical profiles presented graphically in this paper show $\mathrm{O}_{3}$ median values and the 25 th to 75 th percentile range within the $0-12 \mathrm{~km}$ tropospheric column sampled by the DC- 8 aircraft. These medians were obtained by averaging with equal weight the individual profiles within each region over $1 \mathrm{~km}$ altitude bins.

HIPPO flight tracks are illustrated in Fig. 1. The flight segments used for comparison with ATom were binned into the same Pacific latitude and longitude bands as for ATom. HIPPO vertical profile data are derived using the same methodology as for ATom.

All IAGOS flight tracks over the northern and tropical Atlantic are represented in Fig. 1 in green. The latitude bands used to parse IAGOS data are consistent with those used for ATom. The longitude bands are $50-20^{\circ} \mathrm{W}$ in the tropics, $50-10^{\circ} \mathrm{W}$ in the northern midlatitudes, and $110-10^{\circ} \mathrm{W}$ in the northern high latitudes. Variation of the longitude band widths does not significantly affect the $\mathrm{O}_{3}$ distributions measured by IAGOS. Data from all flights from 1994 to 2017 were included in the IAGOS dataset considered here, and they were then divided into two altitude bins (8-10 and 10$12 \mathrm{~km}$ ) in order to better understand the influence of different $\mathrm{O}_{3}$ sources (e.g., anthropogenic, stratospheric) on these two layers of the atmosphere.

We compare the ozonesonde measurements to ATom and HIPPO aircraft data sampled within $500 \mathrm{~km}$ of each ozonesonde launching site, as we expect a robust correlation in the free troposphere within this distance (Liu et al., 2009). We used the surface coordinates of the ozonesonde sites because the in-flight coordinates of ozonesondes are not available for all sites. For comparison with ozonesonde long-term records, we consider three regions of the atmosphere: the boundary layer $(0-2 \mathrm{~km})$, the free troposphere $(2-8 \mathrm{~km})$, and the UTLS $(8-12 \mathrm{~km})$. For each layer, we compared monthly $\mathrm{O}_{3}$ distributions from ozonesondes with the corresponding seasonal $\mathrm{O}_{3}$ distributions from aircraft measurements using the skill score ( $\left.S_{\text {score }}\right)$ metric (Perkins et al., 2007). The $S_{\text {score }}$ is calculated by summing the minimum probability of two normalized distributions at each bin center; therefore, it measures the overlapping area between two probability distribution functions. If the distributions are identical, the skill score will equal $100 \%$ (see Fig. S1 for further examples). Note that the $S_{\text {score }}$ is positively correlated with the size of the bin used to compare distributions. Here we chose a bin size of $5 \mathrm{ppbv}$, which is larger than the combined precision of ATom, HIPPO, and IAGOS measurements but is small enough to separate distinct air masses and their influence on the $\mathrm{O}_{3}$ distribution. Variables such as the distance to each ozonesonde launching site $\left(500 \mathrm{~km}\right.$ in this study), the bin size of the $\mathrm{O}_{3}$ distributions ( $5 \mathrm{ppbv}$ in this study), and the length of each ozonesonde record (full length in this study) can shift the vertically averaged $S_{\text {score }}$ value by up to $8 \%$ (Table S3). Therefore, we treat this $8 \%$ as a rough estimate of the precision of the $S_{\text {score }}$ values presented here.

All three techniques (chemiluminescence, UV absorption, and ECC) used to measure $\mathrm{O}_{3}$ for the datasets analyzed in this work have been shown to provide directly comparable accurate measurements with well-defined uncertainties (Tarasick et al., 2019b). 

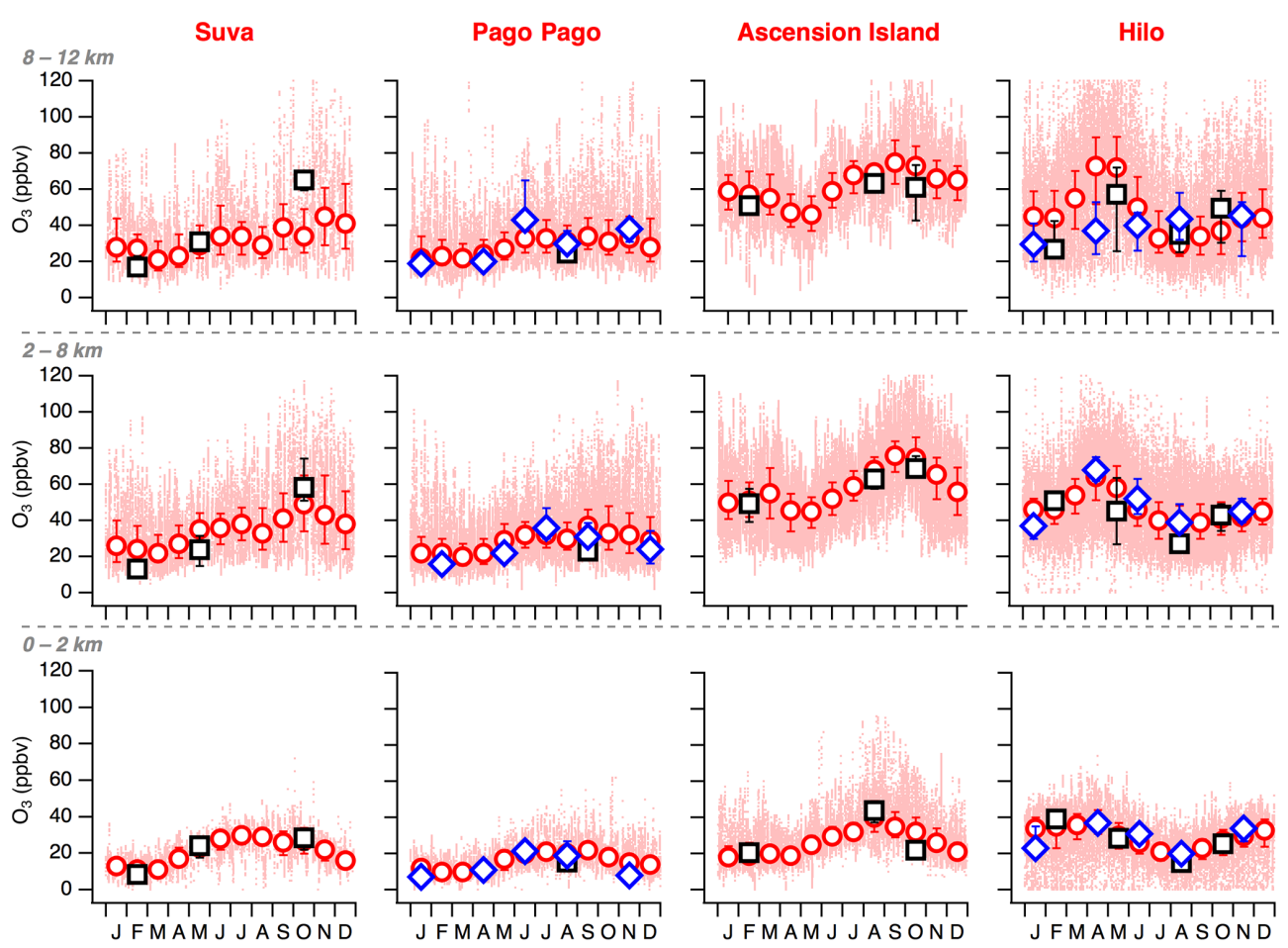

○ Sondes a ATom $\diamond$ HIPPO

Figure 2. Comparison of ATom (black squares) and HIPPO (blue diamonds) monthly median $\mathrm{O}_{3}$ with ozonesonde (red circles) records from the four tropical sites. Markers indicate the median, and the bars indicate the 25th and 75th percentiles. The three rows, from bottom to top, correspond to the boundary layer $(0-2 \mathrm{~km})$, the free troposphere $(2-8 \mathrm{~km})$, and the UTLS $(8-12 \mathrm{~km})$. The pink dots show every $\mathrm{O}_{3}$ data point measured by ozonesondes for the timeframes indicated in Table S2.

\subsection{Back trajectory analysis}

Analysis of back trajectories for air masses sampled during airborne missions is useful to examine the air mass source regions and causes of $\mathrm{O}_{3}$ variability over the Pacific and Atlantic oceans. We calculated $10 \mathrm{~d}$ back trajectories using the TRAJ3D model (Bowman, 1993; Bowman and Carrie, 2002) and National Centers for Environmental Prediction (NCEP) global forecast system (GFS) meteorology. Trajectories were initialized each minute along all of the ATom flight tracks.

\section{Comparison of ATom and HIPPO $\mathrm{O}_{3}$ distributions to longer-term observational records}

Here we use existing ozonesonde and IAGOS observations of $\mathrm{O}_{3}$ at selected locations along the ATom and HIPPO circuits to provide a climatological context for $\mathrm{O}_{3}$ distributions derived from the systematic airborne in situ "snapshots". We quantify how much of $\mathrm{O}_{3}$ variability, occurring on timescales ranging from hours to decades, was captured by the temporally limited HIPPO and ATom missions.

\subsection{Comparison to ozonesondes}

ATom and HIPPO explored the fidelity with which airborne missions represent $\mathrm{O}_{3}$ climatology in the remote troposphere. Here, we show that aircraft-measured median $\mathrm{O}_{3}$ follows the seasonal ozonesonde-measured median $\mathrm{O}_{3}$ cycle at most of the sites studied in this paper, as well as at almost all altitudes - with a few exceptions (Figs. 2, 3). Figure 2 plots the monthly median $\mathrm{O}_{3}$ measurements from the tropical ozonesonde sites in three altitude bins, along with the median values obtained from HIPPO and ATom measurements. Figure 3 plots the same for the extra-tropical sites. Figure 4 correlates the median $\mathrm{O}_{3}$ measured by aircraft in Figs. 2 and 3 with those measured by ozonesondes. At the Eureka site, the winter and spring ATom deployments recorded a significantly lower median $\mathrm{O}_{3}$ compared with the corresponding ozonesonde monthly median $\mathrm{O}_{3}$ in the $0-2 \mathrm{~km}$ range (Fig. 3). Eureka is frequently subject to springtime $\mathrm{O}_{3}$ depletion events at the surface due to atmospheric bromine chemistry, which is well documented by the ozonesonde record (Fig. 3; Tarasick and Bottenheim, 2002). Sampling during $\mathrm{O}_{3}$ depletion events significantly lowered the ATom winter and springtime $\mathrm{O}_{3}$ distributions near this site. In the 2$8 \mathrm{~km}$ range, there is a very good seasonal agreement between 


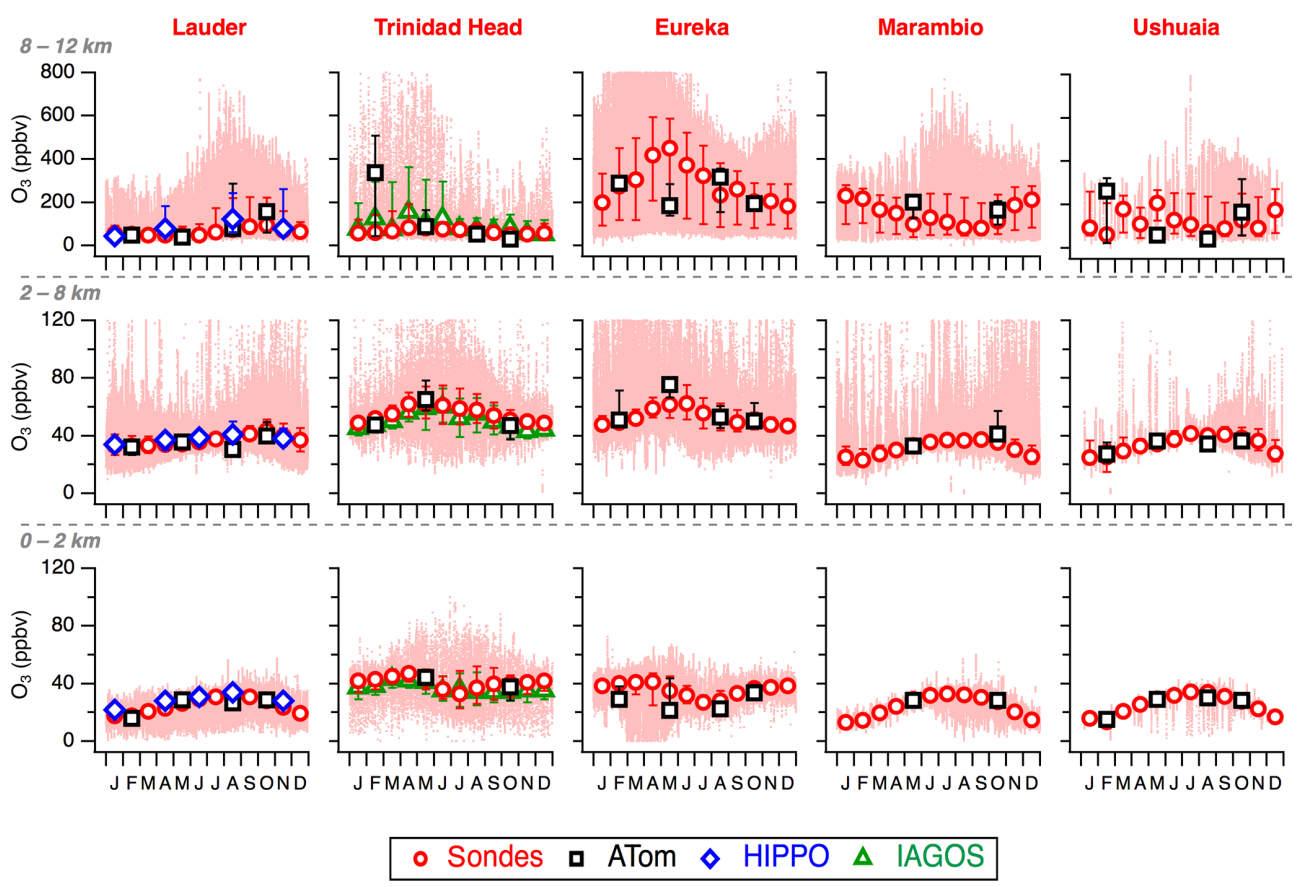

Figure 3. Same as in Fig. 2 but for ozonesonde launching sites located in the middle and high latitudes. $\mathrm{O}_{3}$ data obtained from the IAGOS program (green triangles) during descents into San Francisco Bay Area airports were also added to the Trinidad Head site for comparison.

ATom/HIPPO and the ozonesondes (Fig. 4b). Most seasonal differences are found above $8 \mathrm{~km}$ (e.g., ATom in February at Trinidad Head and in May at Eureka; Fig. 3) and can be linked to the occurrence - or absence - of stratospheric air sampling during ATom and HIPPO. In the absence of stratospheric air mixing ( $<8 \mathrm{~km}$ in Fig. 4), ATom/HIPPO successfully capture a large fraction of $\mathrm{O}_{3}$ climatology everywhere (Fig. 4b, c).

Figures 5 and 6 show vertical profiles of $\mathrm{O}_{3}$ distributions by season at each ozonesonde site, along with comparisons to HIPPO and ATom vertical profiles. Our analysis reveals that $\mathrm{O}_{3}$ distributions derived from the ATom and HIPPO seasonal "snapshots" capture $30 \%-71 \%$ of the $1 \mathrm{~km}$ vertically binned $\mathrm{O}_{3}$ distribution established by long-term ozonesonde climatologies. For the nine ozonesonde sites considered here, ATom and HIPPO captured on average $53 \%, 54 \%$, and $38 \%$ of the $\mathrm{O}_{3}$ distribution in the $0-2,2-8$, and $8-12 \mathrm{~km}$ altitude bins, respectively.

Larger differences between ATom/HIPPO and the ozonesonde records in the UTLS $(8-12 \mathrm{~km})$ can be ascribed to $\mathrm{O}_{3}$ variability from stratospheric-tropospheric exchange, which is not always captured by the ATom and HIPPO missions. This increased $\mathrm{O}_{3}$ variability in the UTLS is well described by the long-term ozonesonde records at Lauder, Trinidad Head, Eureka, Ushuaia, and Marambio (Figs. 3, 6). In these middle- and high-latitude locations in both hemispheres, $\mathrm{O}_{3}$ variability is especially pronounced during winter and spring, time periods favorable to more frequent stratospheric air mixing (Greenslade et al., 2017; Lin et al., 2015a; Tarasick et al., 2019a). Furthermore, the probability of sampling stratospheric air masses at the ATom and HIPPO ceiling altitude $(12-14 \mathrm{~km})$ increases with latitude, resulting in a lower $S_{\text {score }}$ between the ATom/HIPPO and ozonesonde datasets at the extra-tropical sites than at the tropical sites (Fig. S2a and b in the Supplement).

In the boundary layer $(0-2 \mathrm{~km})$ of the remote troposphere, $\mathrm{O}_{3}$ variability is predominantly impacted by loss mechanisms. Ozonesonde records show instances of $\mathrm{O}_{3}$ mixing ratios lower than $10 \mathrm{ppbv}$ throughout the year in the boundary layer at the nine sites studied here (Figs. 2, 3). The lowest $\mathrm{O}_{3}$ mixing ratios are a result of (a) photochemical destruction over the oceans in the tropics (Monks et al., 1998, 2000; Thompson et al., 1993), (b) $\mathrm{O}_{3}$-destroying halogen emissions in polar regions in springtime (e.g., Fan and Jacob, 1992), and (c) transport of $\mathrm{O}_{3}$-poor oceanic air over the midlatitude sites (e.g., Neuman et al., 2012).

ATom and HIPPO best describe the $\mathrm{O}_{3}$ distribution in the free troposphere (2-8 km; Figs. S2a, b). This suggests that airborne campaigns can capture global baseline $\mathrm{O}_{3}$ values, along with the long-range transport of $\mathrm{O}_{3}$ pollution plumes that are often lofted to this altitude range and are responsible for $\mathrm{O}_{3}$ variability.

While ATom consisted of one transect per ocean per season, HIPPO covered the Pacific twice per seasonal deployment (southbound and northbound). The $1 \mathrm{~km}$ binned $S_{\text {score }}$ was on average higher when two combined seasonal HIPPO transects (southbound and northbound) were available to compare to ozonesonde records, as opposed to when compar- 

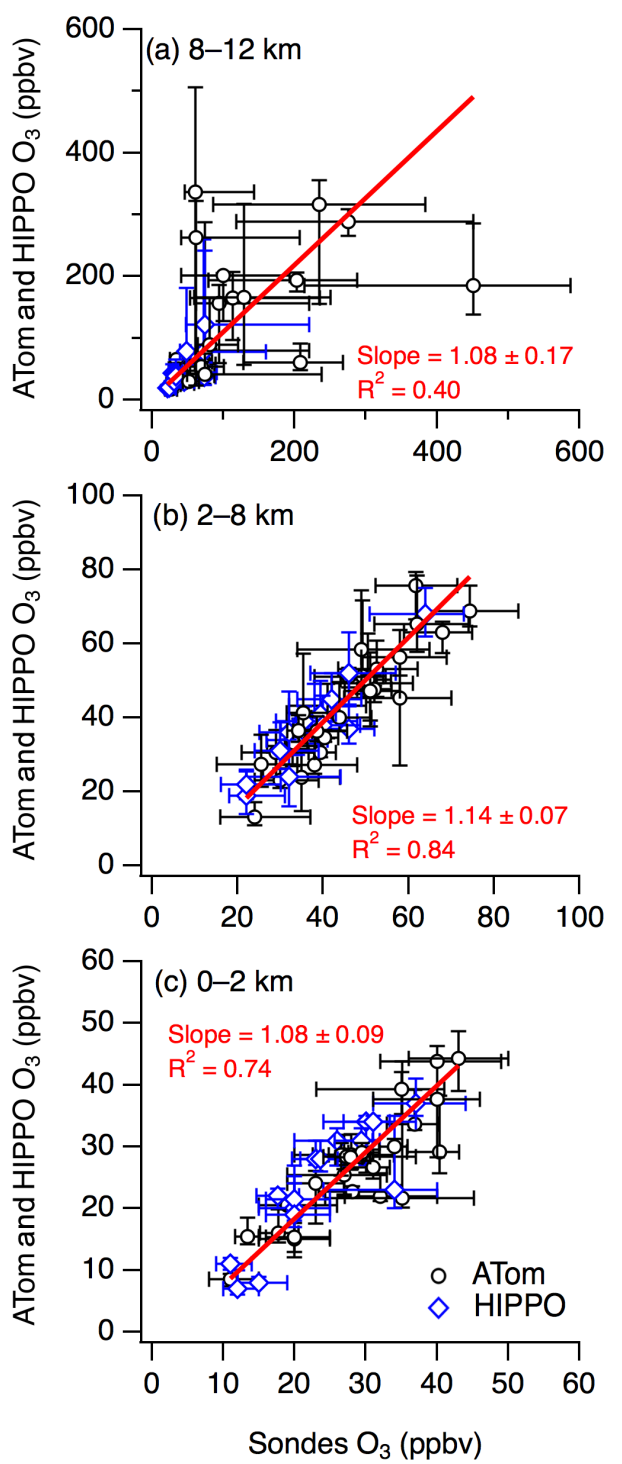

Figure 4. ATom (black circles) and HIPPO (blue diamonds) combined monthly median $\mathrm{O}_{3}$ vs. monthly median $\mathrm{O}_{3}$ from ozonesondes at the nine sites considered in this study. The three panels indicate the correlations for (a) the UTLS $(8-12 \mathrm{~km})$, (b) the free troposphere $(2-8 \mathrm{~km})$, and (c) the boundary layer $(0-2 \mathrm{~km})$. The orthogonal regression fits are two-sided but not weighted.

ing $\mathrm{O}_{3}$ profiles from individual HIPPO transects (Fig. S2c). In addition, two seasonal transects during HIPPO reduced the occurrence of low $S_{\text {score values. The } S_{\text {score }} \text { decrease from fly- }}$ ing only one Pacific transect during ATom was traded for the increase of vertical profiles over the Atlantic Basin, which was not sampled during HIPPO. Future airborne missions with multiple seasonal vertical profiles over large-scale regions would be ideal to better depict the full range of tropospheric $\mathrm{O}_{3}$ variability.

\subsection{Comparison to IAGOS}

IAGOS $\mathrm{O}_{3}$ and $\mathrm{CO}$ observations in the northern Atlantic UTLS provide a measurement-based climatology at commercial aircraft cruise altitudes for comparison to ATom. Simultaneous measurements of $\mathrm{O}_{3}$ and $\mathrm{CO}$ are of particular interest because $\mathrm{CO}$ provides a long-lived tracer of continental emissions, which helps to differentiate $\mathrm{O}_{3}$ sources (Cohen et al., 2018). We note that while IAGOS measurements encompass hundreds of seasonal flights (depending on the region), ATom sampled within each latitude band and season on one or two flights only (Fig. 1). Thus, variability in the UT that occurred on timescales longer than a day was not captured by ATom. Consequently, it is not surprising to see that ATom systematically under-sampled tropospheric $\mathrm{O}_{3}$ (and $\mathrm{CO}$ ) variability compared with IAGOS at all latitudes in the northern Atlantic (Figs. 7, 8). ATom captured on average $40 \%$ of the $\mathrm{O}_{3}$ variability measured by IAGOS in the Atlantic UTLS (Fig. 7), which is on par with the $S_{\text {score }}$ of $38 \%$ obtained when comparing ATom and HIPPO to ozonesonde data (see Sect. 3.1).

In the middle and high latitudes, the shapes of the $\mathrm{O}_{3}$ vs. CO scatterplots from IAGOS data demonstrate that distinct sources contribute to $\mathrm{O}_{3}$ levels in the UTLS (Fig. 8a, b; Gaudel et al., 2015). The high $\mathrm{O}_{3}(>150 \mathrm{ppbv})$-low $\mathrm{CO}$ $(<100 \mathrm{ppbv})$ range corresponds to intrusions of stratospheric air, which were mostly sampled in the spring season during ATom, supporting previous observations of increased stratospheric air mixing during this season (Lin et al., 2015a; Tarasick et al., 2019a). The low $\mathrm{O}_{3}(<50 \mathrm{ppbv})-$ low $\mathrm{CO}$ $(<100 \mathrm{ppbv})$ range corresponds to the tropospheric baseline air, whereas the intermediate $\mathrm{O}_{3}(50-120 \mathrm{ppbv})$-high $\mathrm{CO}$ $(>100 \mathrm{ppbv}$ ) range generally represents the influence of air masses transported from continental regions. During ATom, high $\mathrm{O}_{3}$ and low $\mathrm{CO}$ in the middle- and high-latitude UTLS were typical of stratospheric and baseline tropospheric air mixing.

$\mathrm{O}_{3}$ measured during IAGOS rarely exceeds $150 \mathrm{ppbv}$ in the northern tropical Atlantic UTLS (Fig. 8c). This is expected because the tropical tropopause is typically situated between an altitude of 13 and $17 \mathrm{~km}$ and IAGOS flights typically cruise below $12 \mathrm{~km}$. Therefore, instances of stratospheric intrusions at IAGOS flight altitudes are limited. $\mathrm{O}_{3}$ measured during ATom in the tropical Atlantic above $8 \mathrm{~km}$ was generally positively correlated with $\mathrm{CO}$, showing the contribution of tropospheric $\mathrm{O}_{3}$ production from continental sources reaching high altitudes. Given this variability, the ATom data do not capture the extrema of UTLS $\mathrm{O}_{3}$ variability in the IAGOS measurements (Figs. 7, 8). However, the most frequently measured $\mathrm{O}_{3}$ and $\mathrm{CO}$ values from ATom overlap with the most frequently measured $\mathrm{O}_{3}$ and $\mathrm{CO}$ values from IAGOS (contours in Fig. 8), suggesting that ATom captured the mode of the $\mathrm{O}_{3}$ and $\mathrm{CO}$ distributions from IAGOS in the northern Atlantic UTLS. 

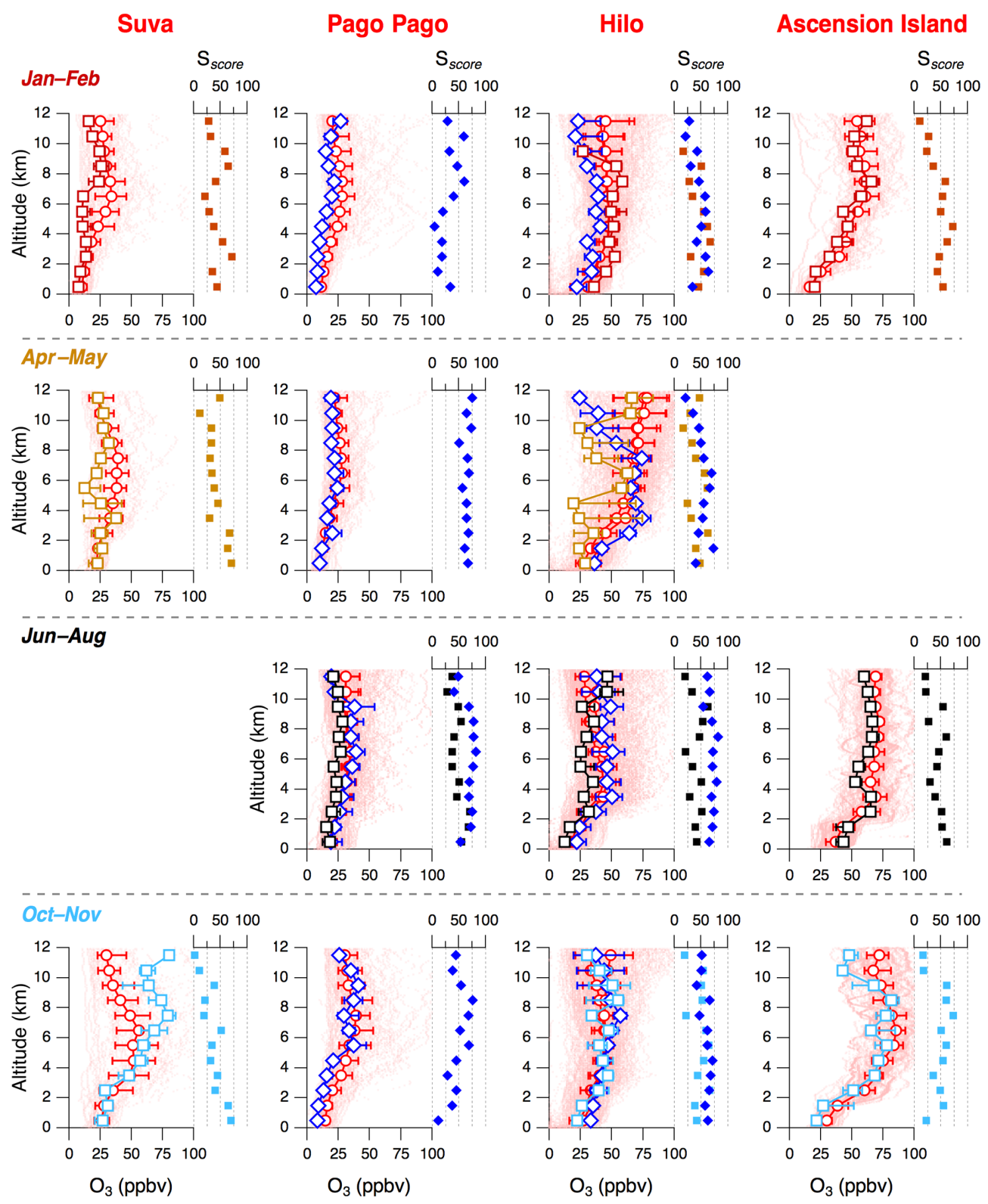

Figure 5. Seasonal comparison of $1 \mathrm{~km}$ vertically binned ATom (colored squares) and HIPPO (blue diamonds) median $\mathrm{O}_{3}$ with ozonesonde (red circles) records at four sites in the tropics (Suva in Fiji, Pago Pago in American Samoa, Hilo in Hawaii, and Ascension Island). Markers indicate the median, and the bars are the 25 th and 75 th percentiles. The $S_{\text {score }}$ is a metric of how well ATom and HIPPO $1 \mathrm{~km}$ binned $\mathrm{O}_{3}$ probability distribution functions (PDFs) overlap with the corresponding $1 \mathrm{~km}$ binned $\mathrm{O}_{3}$ PDFs from ozonesondes. The $S_{\text {score }}$ shown using squares compares ATom with ozonesondes, and the $S_{\text {score }}$ shown using blue diamonds compares HIPPO with ozonesondes. The pink dots show every $\mathrm{O}_{3}$ data point measured by ozonesondes for the timeframes indicated in Table $\mathrm{S} 2$.

\section{$4 \quad \mathrm{O}_{3}$ distributions in the remote troposphere from ATom and HIPPO}

We have established the fidelity of ATom and HIPPO $\mathrm{O}_{3}$ data by comparison to measurement-based climatologies of tropospheric $\mathrm{O}_{3}$ from well-established ozonesonde and commercial aircraft monitoring programs. In the following sections, we exploit the systematic nature of the ATom and HIPPO vertical profiles to provide a global-scale picture of tropospheric $\mathrm{O}_{3}$ distributions in the remote atmosphere. Figure 9 presents the altitudinal, latitudinal, and seasonal distribution of tropospheric $\mathrm{O}_{3}$ during ATom and HIPPO. Higher $\mathrm{O}_{3}$ was measured during ATom and HIPPO in the Northern Hemisphere $(\mathrm{NH})$ than in the Southern Hemisphere $(\mathrm{SH})$, both in the Pacific and in the Atlantic. This distribution gradient has previously been shown by global $\mathrm{O}_{3}$ mapping from modeling, satellite, and ozonesonde analyses (e.g., Hu et al., 

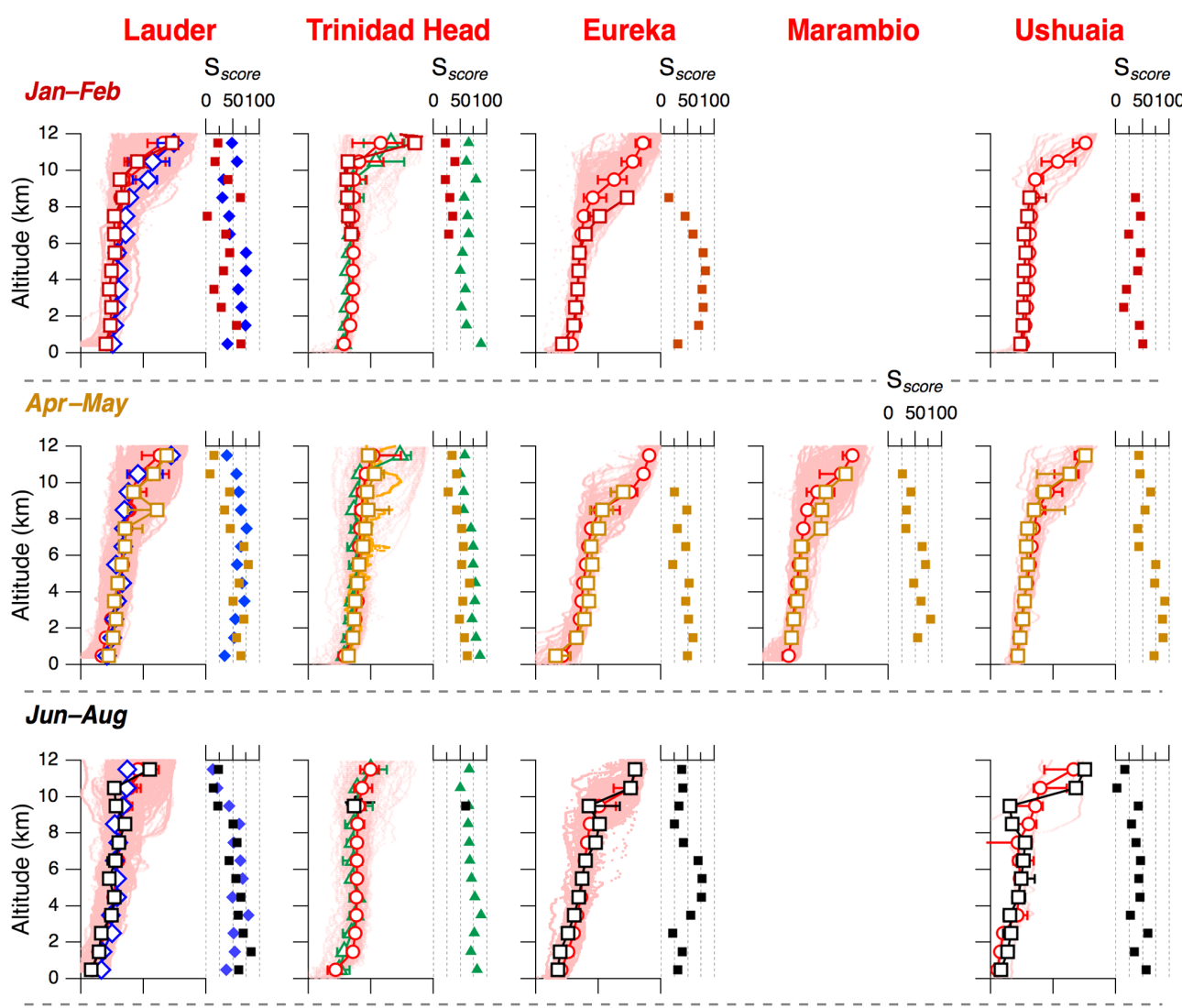

Oct-Nov

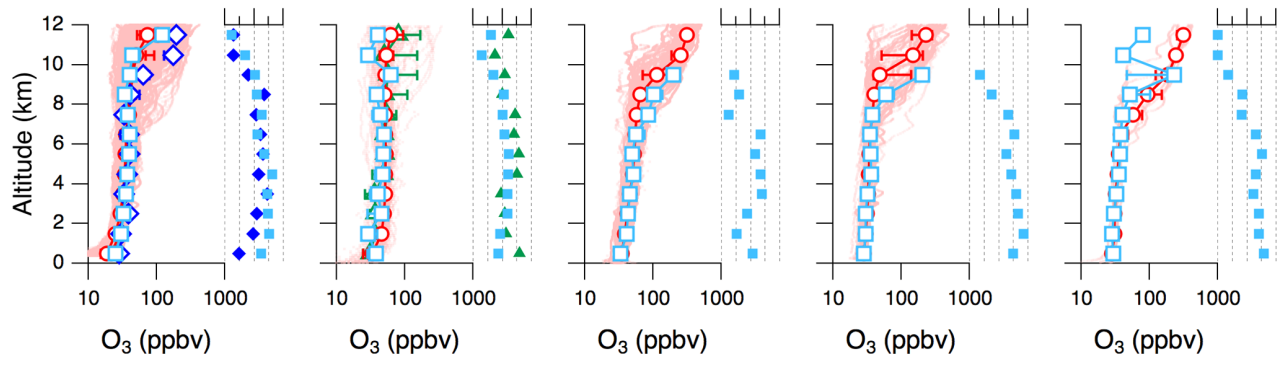

Figure 6. Same as in Fig. 5 but for ozonesonde launching sites located in middle and high latitudes (Lauder in New Zealand, Trinidad Head in the USA, Eureka in Canada, Ushuaia in Argentina, and Marambio in Antarctica). $\mathrm{O}_{3}$ data obtained from the IAGOS program (green triangles) during descents into San Francisco Bay Area airports were also added to the Trinidad Head site for comparison.

2017; Liu et al., 2013). This finding holds true throughout the tropospheric column from 0 to $8 \mathrm{~km}$, both in the middle and high latitudes (Fig. S3). In the midlatitudes below $8 \mathrm{~km}$, median $\mathrm{O}_{3}$ ranged between 25 and $45 \mathrm{ppbv}$ in the $\mathrm{SH}$ and between 35 and $65 \mathrm{ppbv}$ in the $\mathrm{NH}$. In the high latitudes below $8 \mathrm{~km}$, median $\mathrm{O}_{3}$ ranged between 30 and $45 \mathrm{ppbv}$ in the $\mathrm{SH}$ and between 40 and $75 \mathrm{ppbv}$ in the NH. Notable features in the global $\mathrm{O}_{3}$ distribution are discussed in more detail in the following sections. Figure 10 presents the vertically resolved distribution of tropospheric $\mathrm{O}_{3}$ from 0 to $12 \mathrm{~km}$ for the Atlantic (ATom in green) and for the Pacific (ATom in pink and

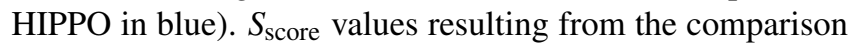
of the HIPPO and ATom Pacific distributions are shown us- ing blue diamonds, and values resulting from the comparison of ATom Atlantic and Pacific distributions are shown using pink squares. Figure 11 is derived from Fig. 10 and gives the $S_{\text {score values against altitude in panel (a), as well as the rela- }}$ tive difference of median $\mathrm{O}_{3}$ from 0 to $8 \mathrm{~km}$ in panel (b).

\subsection{Tropics}

\subsubsection{Vertical distribution}

$\mathrm{O}_{3}$ is at a minimum in the tropical marine boundary layer (MBL), especially over the Pacific (Fig. 10a). The lowest measured $\mathrm{O}_{3}$ in this region was $5.4 \mathrm{ppbv}$ in May during ATom, and 3.5 ppbv in January during HIPPO. The tropical 

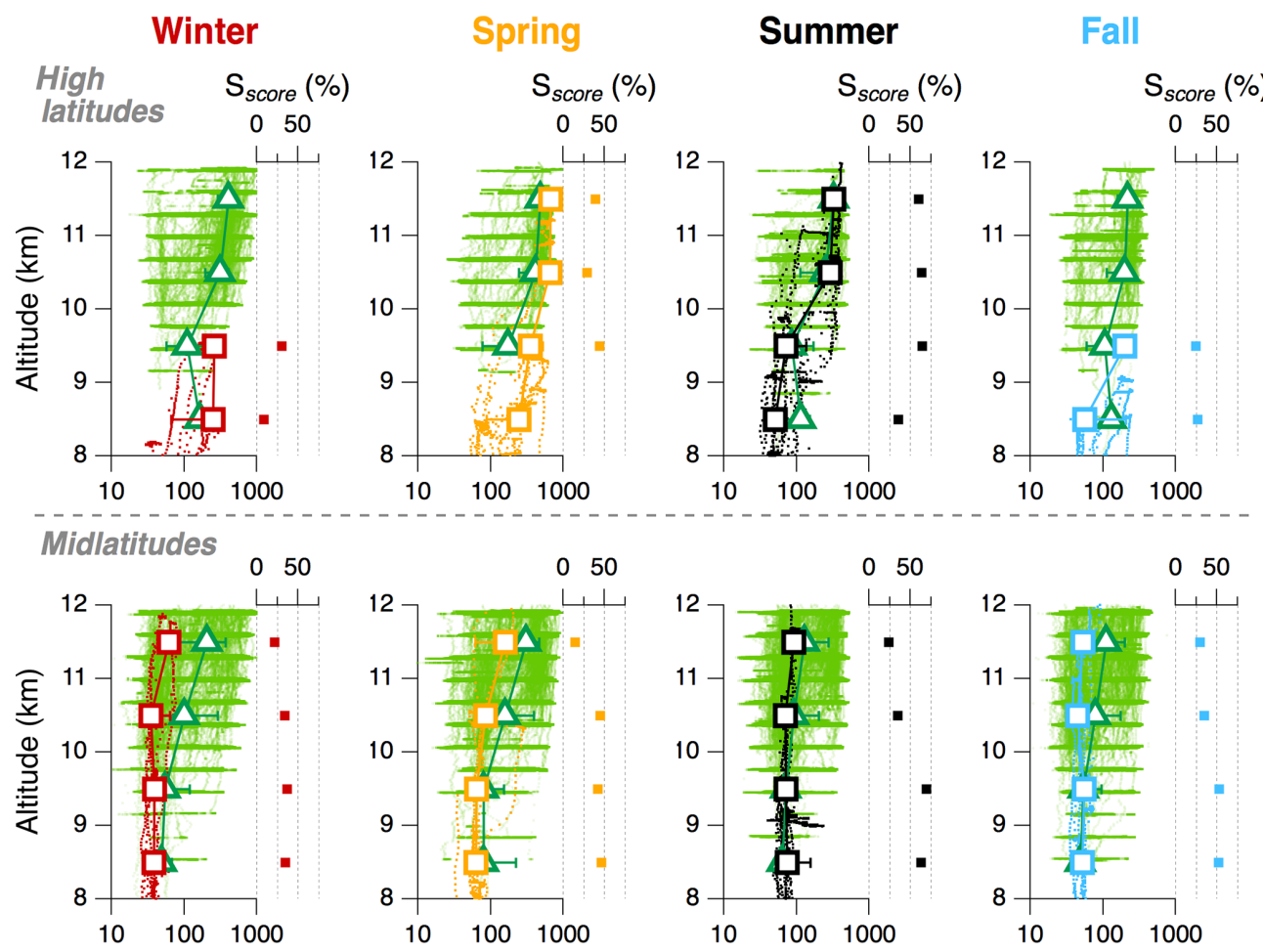

$0 \quad 50$

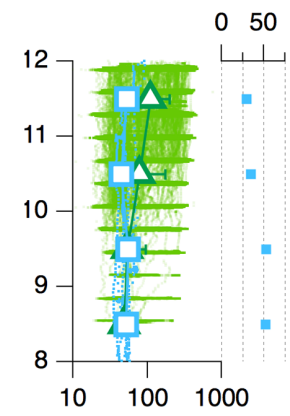

Tropics
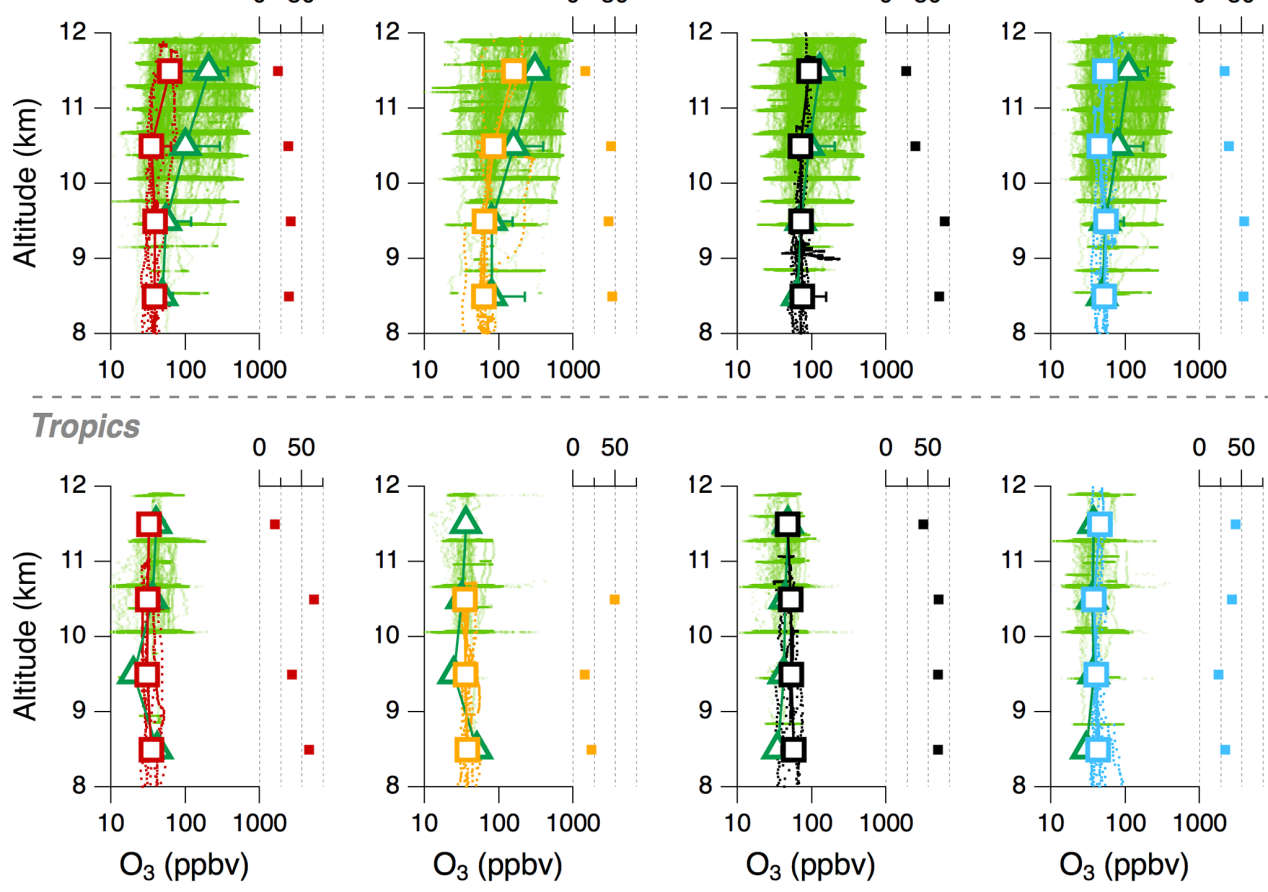

- -ATom $-\triangle$-IAGOS

Figure 7. Seasonal comparison of $1 \mathrm{~km}$ binned ATom (colored squares) median $\mathrm{O}_{3}$ with IAGOS (green triangles) in the northern Atlantic UTLS. Markers indicate the median, and the bars are the 25 th and 75 th percentiles. The three different rows indicate the latitudinal bands. The four columns indicate the seasons. The green dots show every $\mathrm{O}_{3}$ data point measured by IAGOS flights for the timeframe indicated in Table S1.

MBL is a net $\mathrm{O}_{3}$ sink owing to very slow $\mathrm{O}_{3}$ production rates - NO levels averaged $22 \pm 12$ pptv in the Pacific and Atlantic MBL during ATom - and rapid photochemical destruction rates of $\mathrm{O}_{3}$ in a sunny, humid environment (Kley et al., 1996; Parrish et al., 2016; Thompson et al., 1993). Deep stratospheric intrusions into the Pacific MBL were not observed in ATom or HIPPO, in contrast to reports from previous studies (e.g., Cooper et al., 2005; Nath et al., 2016). In the tropics, marine convection within the intertropical convergence zone (ITCZ) is associated with relatively low $\mathrm{O}_{3}$ values throughout the tropospheric column, with median $\mathrm{O}_{3}$ mixing ratios less than $25 \mathrm{ppbv}$ below an altitude of $4 \mathrm{~km}$ in the tropical Pacific (Fig. 10a; Oltmans et al., 2001). The relative difference between ATom Atlantic and Pacific median $\mathrm{O}_{3}$ in the tropics below $8 \mathrm{~km}$ is consistently higher than a factor of 1.5 , with an average $S_{\text {score }}$ of $43 \%$ (Figs. 10a, 11b). We ascribe this difference to $\mathrm{O}_{3}$ production from biomass burning (BB) emissions in the continental regions surrounding the tropical Atlantic; back trajectories from the ATom flight tracks show the tropical Atlantic is strongly affected by transport from BB source regions in both Africa and South America (Fig. S4; Jensen et al., 2012; Sauvage et al., 2006; Stauffer 


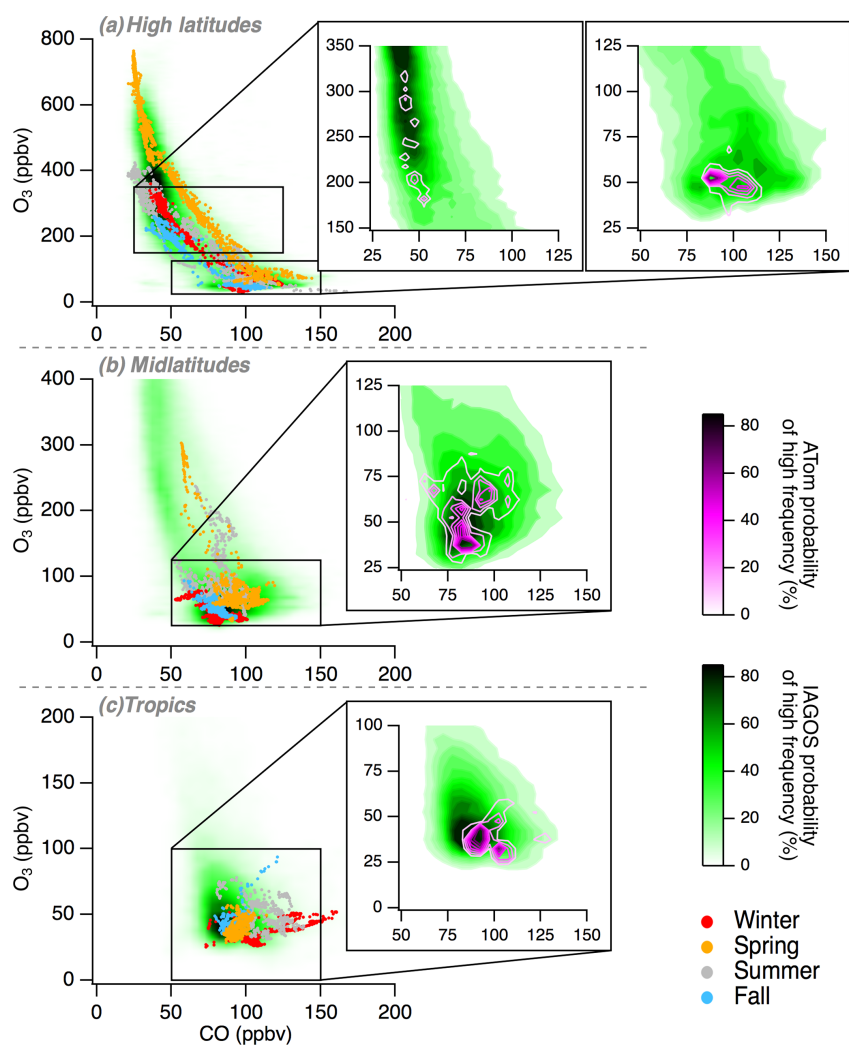

Figure 8. IAGOS and ATom seasonal $\mathrm{O}_{3}$ vs. CO scatterplots, with insets showing the most frequent $\mathrm{O}_{3}$ values measured during IAGOS and ATom. ATom seasonal deployments are colored according to the legend. The frequency gradient of the $\mathrm{O}_{3}$ counts is illustrated by the color scales (green for IAGOS and magenta for ATom). ATom measurements have been combined for the frequency gradients shown in the insets. The probability of high frequency refers to the probability of finding frequently measured $\mathrm{O}_{3}$ values within the contour boundaries.

et al., 2018; Thompson et al., 2000). In addition, the positive correlation of $\mathrm{O}_{3}$ enhancements with black carbon (Katich et al., 2018) and reactive nitrogen species (Chelsea Thompson, personal communication, 2017) also indicate BB influence. Although ATom and HIPPO data show evidence of extensive and widespread $\mathrm{BB}$ influence on $\mathrm{O}_{3}$ in the Pacific as well, $\mathrm{O}_{3}$ mixing ratios are consistently more elevated throughout the tropospheric column in the Atlantic. One reason for this is the closer proximity of the mid-ocean Atlantic flight tracks to $\mathrm{O}_{3}$ precursor source regions. These findings confirm studies that previously highlighted the impact of African BB emissions on $\mathrm{O}_{3}$ production in the tropical Atlantic (e.g., Andreae et al., 1994; Fishman et al., 1996; Jourdain et al., 2007; Williams et al., 2010). Lightning $\mathrm{NO}_{x}$ also play a role in the buildup of $\mathrm{O}_{3}$ over the tropical Atlantic at certain times of year (Moxim and Levy, 2000; Pickering et al., 1996).

\subsubsection{Seasonality}

The seasonal variation of vertical profiles of $\mathrm{O}_{3}$ in the tropics is lower throughout the column compared with the extratropics (Fig. 12), in part due to less stratospheric influence at the highest tropical altitudes. The remoteness of the tropical Pacific flight paths from continental pollution sources also drives the lower seasonal variability here compared with the tropical Atlantic, where the BB influence peaks in JuneAugust and October-November, characterized by high $\mathrm{O}_{3}$ (>75 ppbv) and high CO (>100 ppbv) (Fig. 13f), significantly increasing the $\mathrm{O}_{3}$ vertical distribution compared with the other seasons (Fig. 12c, h, m). Finally, photochemistry, which regulates the $\mathrm{O}_{3}$ net balance in the troposphere, is less seasonally variable in the tropics than in the extra-tropics, where the photolysis frequency of $\mathrm{O}_{3}, j\left(\mathrm{O}_{3}\right)$, and the photochemical production of $\mathrm{O}_{3}$ fluctuate annually with solar zenith angle.

\subsection{3 $\mathrm{O}_{3}$ minima and maxima}

Coincident $\mathrm{O}_{3}$ and $\mathrm{CO}$ enhancements were observed in the tropical Atlantic for each ATom circuit (Figs. 9, 13f), suggesting a year-round influence of continental emissions and distinctive dynamics in this region (Krishnamurti et al., 1996; Thompson et al., 1996). In the tropical Pacific, the AprilMay period stands out due to an $\mathrm{O}_{3}$ and $\mathrm{CO}$ enhancement episode during HIPPO (Fig. 9) that was attributed to the transport of anthropogenic and BB emissions from Southeast Asia (Shen et al., 2014). Deep convection in the tropics brings $\mathrm{O}_{3}$-poor ( $<15 \mathrm{ppbv}$ ) air to the upper troposphere (Kley et al., 1996; Pan et al., 2015; Solomon et al., 2005). However, the spatial extent of these events remains poorly constrained. Results from ATom and HIPPO suggest that deep convection can loft $\mathrm{O}_{3}$-poor air at least up to $12 \mathrm{~km}$ (the altitude ceiling of this study) in the tropical Pacific and occurred more frequently between January and May (Fig. 12c, h). During the rest of the year, $\mathrm{O}_{3}$-poor air was typically confined below $4 \mathrm{~km}$. Conversely, $\mathrm{O}_{3}$-poor air is confined to the first $2 \mathrm{~km}$ in the tropical Atlantic (Fig. S5). Meteorological analysis of tropical ozonesondes shows that subsidence of higher- $\mathrm{O}_{3}$ air aloft over the Atlantic is one reason $\mathrm{O}_{3}$-poor air is found only in the boundary layer (Thompson et al., 2000, 2012).

\subsection{Middle and high latitudes}

\subsubsection{Vertical distribution}

In the middle and high latitudes, tropospheric $\mathrm{O}_{3}$ was generally at a minimum in the MBL and increased with altitude. Above $8 \mathrm{~km}$, increasing $\mathrm{O}_{3}$ with altitude (Fig. 10b-e) and its persistent anticorrelation with $\mathrm{CO}$ (Fig. 13) points to stratospheric air sampling as the cause for higher $\mathrm{O}_{3}$ variability in the extra-tropical UTLS, especially at high latitudes where the tropopause is lower and wave breaking of the po- 

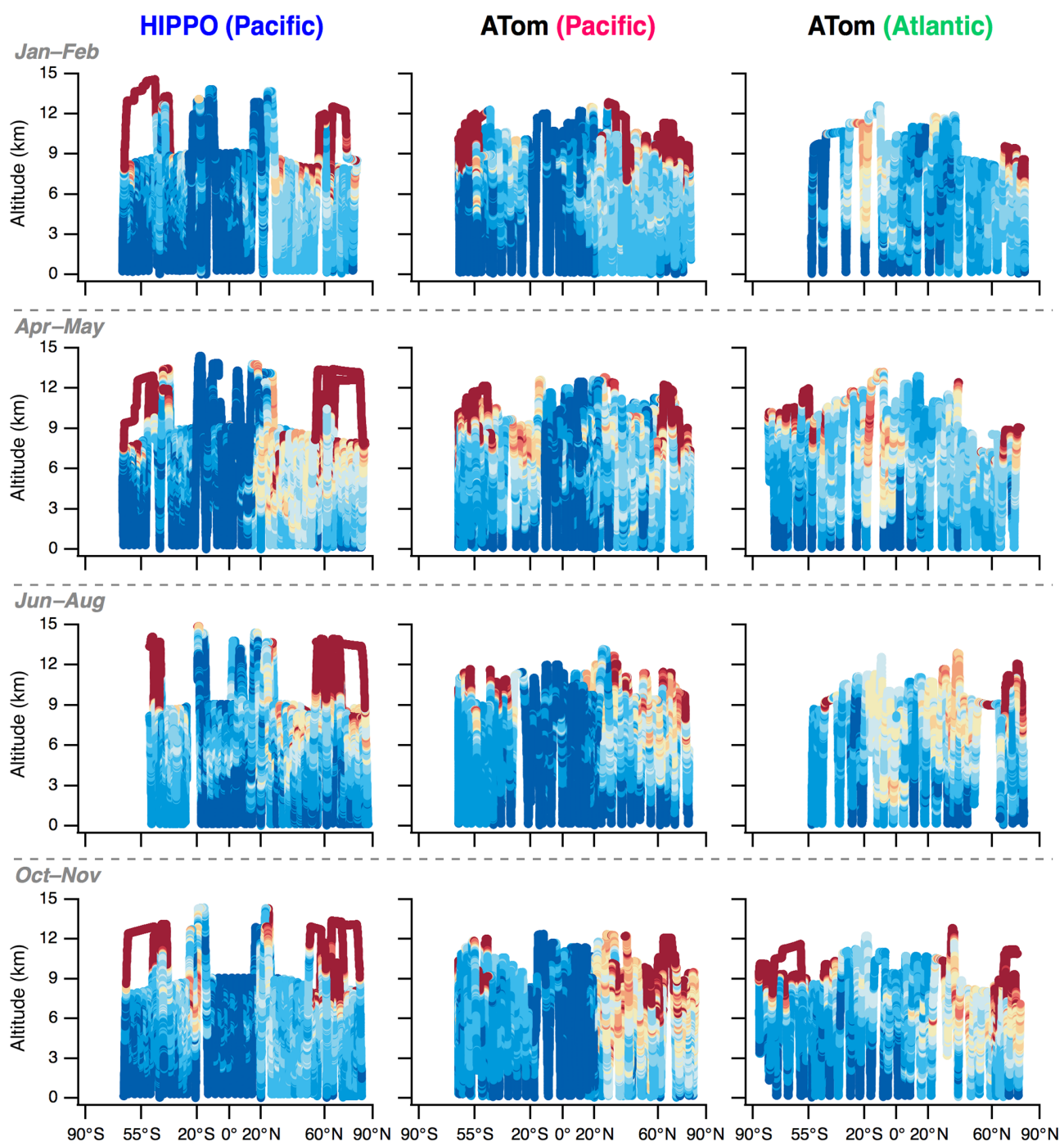

Latitude

Latitude

Latitude

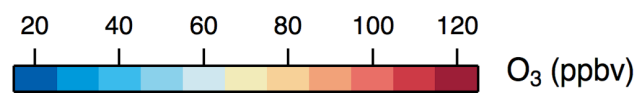

Figure 9. Global-scale distribution of tropospheric $\mathrm{O}_{3}$ for each ATom and HIPPO seasonal deployment. The rows separate the seasonal deployments, whereas the columns indicate the mission and the ocean basin. The $\mathrm{O}_{3}$ color scale ranges from 20 to 120 ppbv, and all values outside of this range are shown using the same extremum color (red for values $>120$ ppbv and blue for values $<20$ ppbv). HIPPO deployments in June and August were combined.

lar jet streams can lead to stratospheric intrusions. As a result, the $S_{\text {score }}$ decrease above $8 \mathrm{~km}$, summarized in Fig. 11a, is ascribed to variability in the influence of stratospheric air. ATom has detected little change in the $\mathrm{O}_{3}$ distribution over the Pacific Ocean since HIPPO, with a $S_{\text {score }}$ averaging $74 \%$ in the $0-8 \mathrm{~km}$ range. The relative difference between median $\mathrm{O}_{3}$ values from HIPPO and ATom in the Pacific is generally lower than $20 \%$ (Fig. 11b). Similarly, the relative difference between the median $\mathrm{O}_{3}$ mixing ratios between ATom Atlantic and Pacific below $8 \mathrm{~km}$ is consistently lower than $20 \%$, with an average $S_{\text {score }}$ of $75 \%$ (Fig. 11b). The southern high latitudes are the only region where the $S_{\text {score }}$ below $8 \mathrm{~km}$ occasionally fell below $60 \%$ (Fig. 10e). However, a lower $S_{\text {score }}$ was expected there as the Atlantic vertical profile is based on only two seasonal flights to Antarctica, whereas there were four seasonal flights in the Pacific. Additionally, HIPPO was less spatially extensive - resulting in fewer data points - in this latitude bin compared with ATom (Fig. 1), which could explain the low $S_{\text {score }}$ values when comparing the two missions (Fig. 10e). Nevertheless, the similar $\mathrm{O}_{3}$ distribution in the extra-tropical free troposphere above the two oceans is consistent with an $\mathrm{O}_{3}$ lifetime that is sufficiently long for 


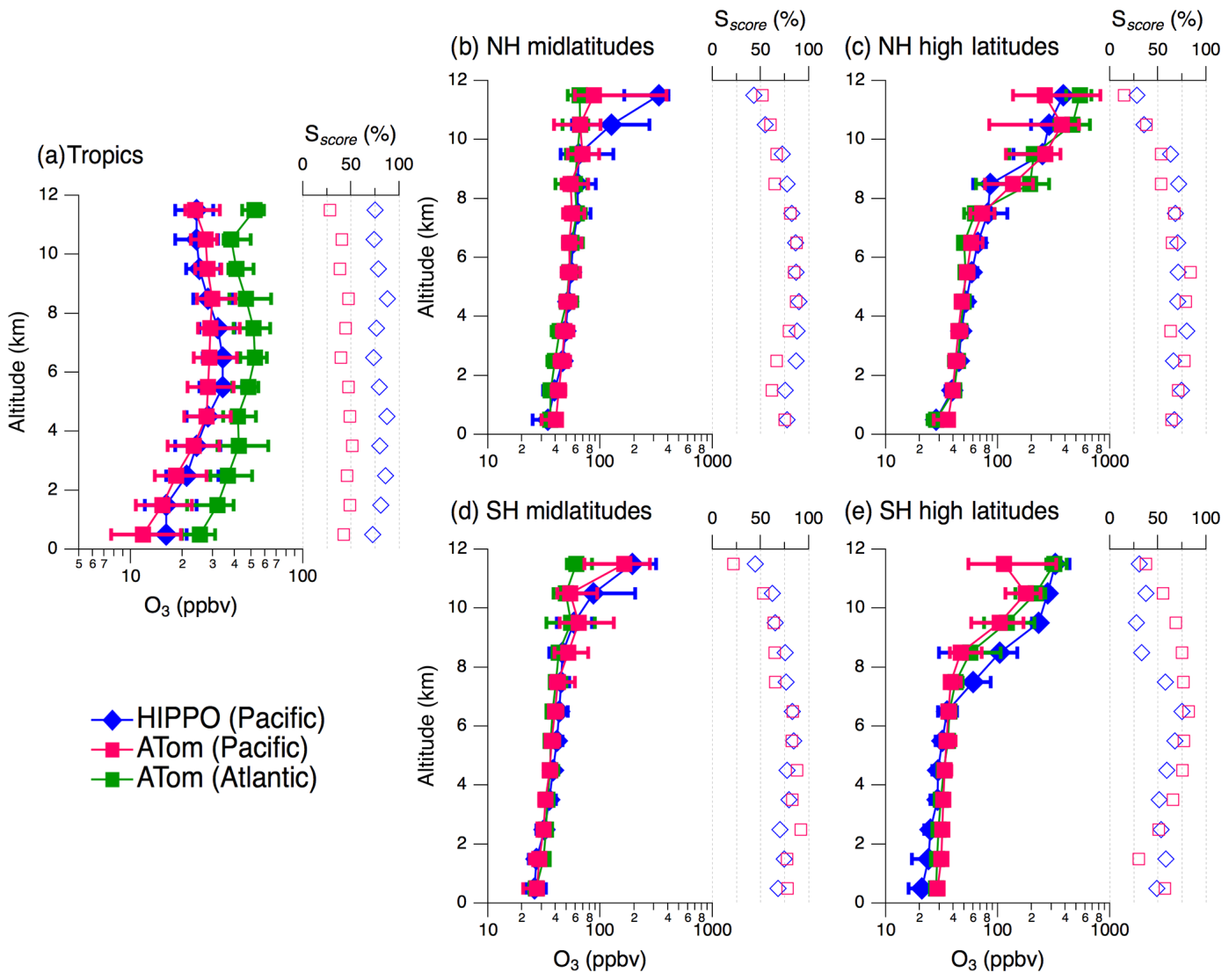

Figure 10. Vertically resolved $\mathrm{O}_{3}$ distributions from 0 to $12 \mathrm{~km}$ are plotted for the Atlantic (ATom in green) and for the Pacific (ATom in pink and HIPPO in blue). The five broad latitude regions correspond to the data parsing illustrated by Fig. 1. Markers indicate median $\mathrm{O}_{3}$, and bars are the 25th and 75th percentiles, per $1 \mathrm{~km}$ altitude bin. Note the $\log$ scale on the $x$ axis. $S_{\text {score }}$ values resulting from the comparison of HIPPO and ATom Pacific distributions are shown using blue diamonds, and values resulting from the comparison of ATom Atlantic and Pacific distributions are shown using pink squares.
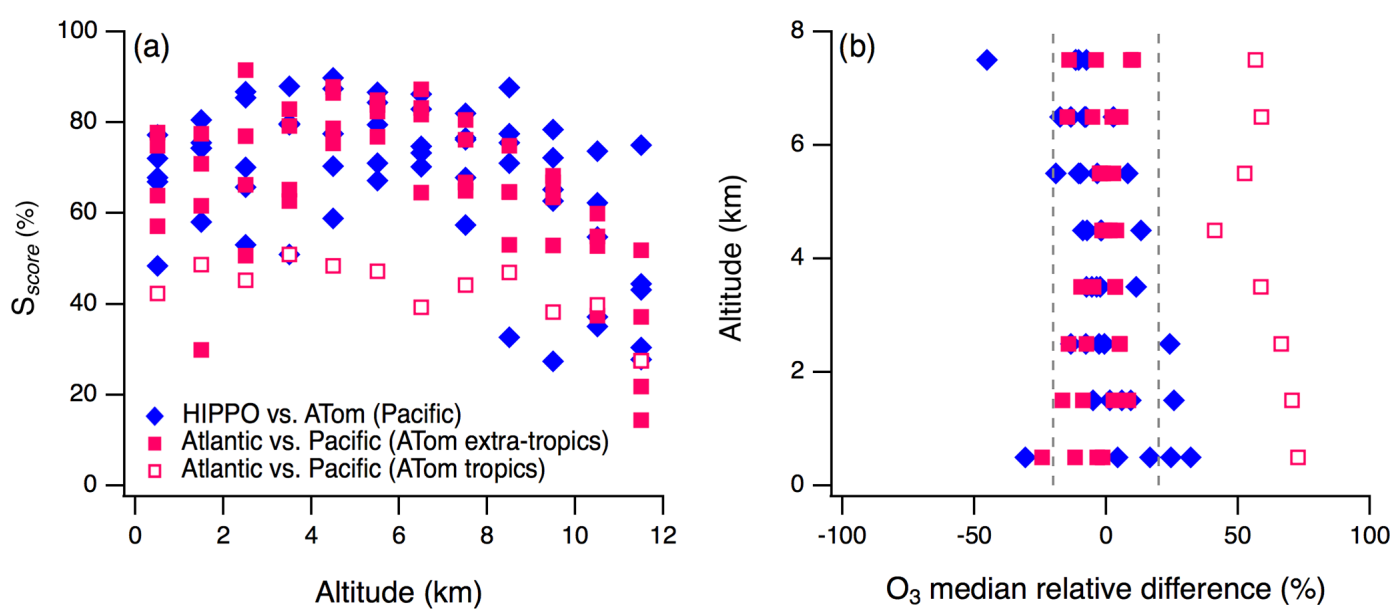

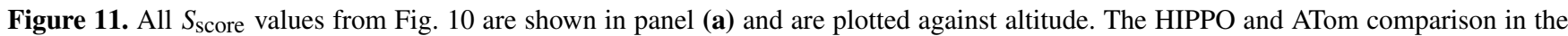
Pacific Basin is shown using blue diamonds, and a comparison of the Atlantic and Pacific basins during ATom is shown using filled pink squares for the extra-tropics and open pink squares for the tropics. The relative difference of median $\mathrm{O}_{3}$ from 0 to $8 \mathrm{~km}$ given in Fig. 10 is shown in panel (b), using the same color and marker code as in panel (a). The dotted gray lines indicate a relative difference of $20 \%$. 
SH high latitudes SH midlatitudes $\quad$ Tropics NH midlatitudes NH high latitudes
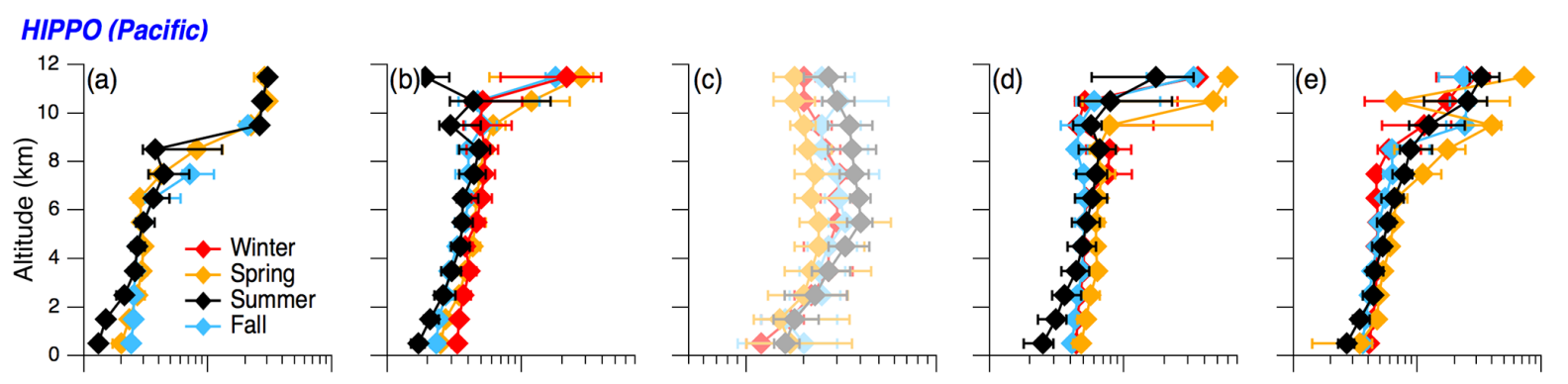

ATom (Pacific)
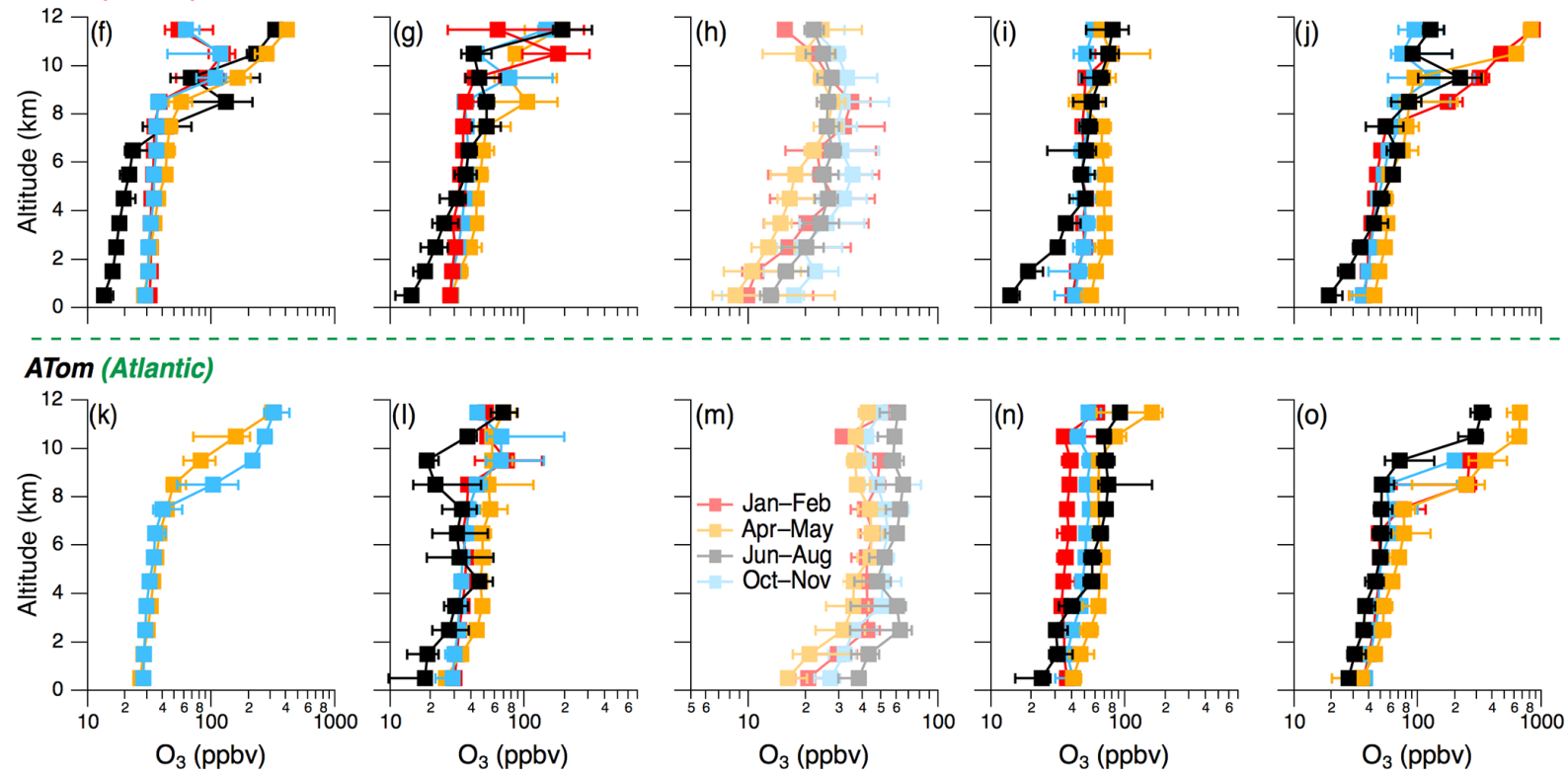

Figure 12. Seasonal variability of the regional $\mathrm{O}_{3}$ distribution in the Pacific (HIPPO in the top row and ATom in the middle row) and in the Atlantic (ATom in the bottom row). The colors designate the local seasons with red as winter, gold as spring, black as summer, and blue as fall (the corresponding months are indicated for the tropics, using lighter colors). The markers and associated bars correspond to the median, 25 th and 75th percentiles, respectively, of the $\mathrm{O}_{3}$ distribution in every $1 \mathrm{~km}$ altitude bin. Note the logarithmic scale on the $x$ axes in all panels and the changing scale with latitudinal bin.

rapid zonal transport to smooth out variations in baseline $\mathrm{O}_{3}$ distribution in the remote troposphere, across a relatively wide range of longitudes (Fig. 10b-e). The comparison of $\mathrm{O}_{3}$ seasonal cycles at remote ozonesonde launching sites of the northern midlatitudes yields similar results and further supports this conclusion (Logan, 1985; Parrish et al., 2020). However, the similarity of the $\mathrm{O}_{3}$ distribution in the extratropical free troposphere above the Atlantic and Pacific is not always evident in satellite-, modeling-, or ozonesondederived maps (Gaudel et al., 2018; Hu et al., 2017; Ziemke et al., 2017). Additionally, studies of the spatial representativeness of tropospheric $\mathrm{O}_{3}$ monitoring networks have also concluded that tropospheric $\mathrm{O}_{3}$ distributions varied significantly with longitude, especially in the northern middle and high latitudes over continents (Liu et al., 2013; Tilmes et al., 2012). In contrast, the ATom findings stem from $\mathrm{O}_{3}$ measurements predominantly over the oceans, which likely reveal a different picture of $\mathrm{O}_{3}$ longitudinal distribution away from regional precursor emissions.

\subsubsection{Seasonality}

The extra-tropical vertical profiles of $\mathrm{O}_{3}$ vary seasonally during ATom and HIPPO. The summer season in the middle and high latitudes was remarkable over both oceans and hemispheres for the steep $\mathrm{O}_{3}$ gradients in the tropospheric column (Fig. 12 in black). In the MBL, median $\mathrm{O}_{3}$ was consistently under $25 \mathrm{ppbv}$ in the summer, whereas $\mathrm{O}_{3}$ was over $25 \mathrm{ppbv}$ in other seasons. Low $\mathrm{O}_{3}$ in the MBL in summer reflects the enhanced $\mathrm{O}_{3}$ photochemical destruction in this $\mathrm{NO}_{x}$-limited region. Photochemical destruction decreases in dry air in the upper troposphere, leading to the steep $\mathrm{O}_{3}$ gradients observed in this region. The summer $\mathrm{O}_{3}$ minimum was especially apparent in the high latitudes of the southern Pacific during 


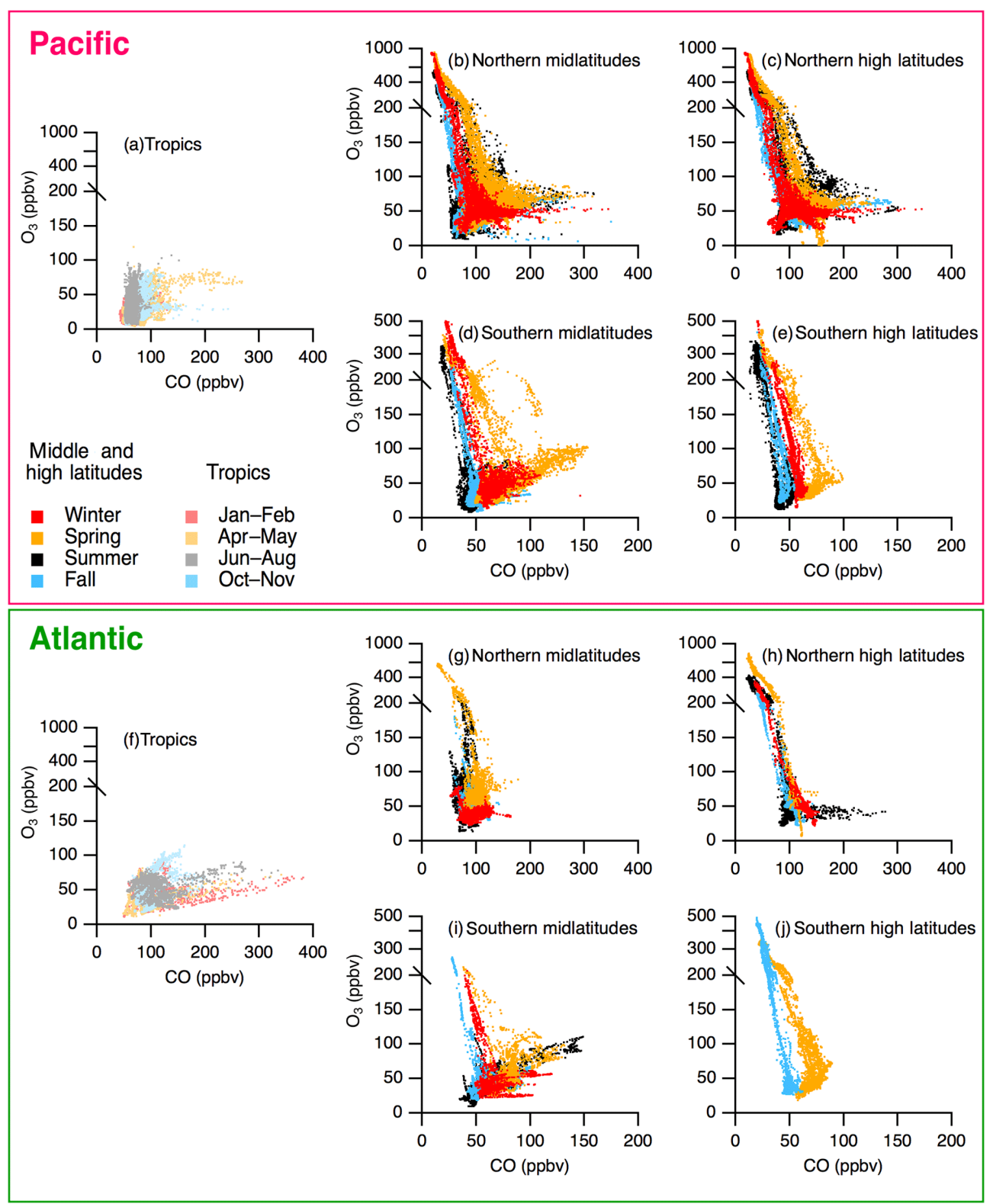

Figure 13. $\mathrm{O}_{3}$ vs. CO plots using combined ATom and HIPPO data. Each panel denotes a different latitudinal band in each basin. Seasonal deployments are colored according to the legend. Note the logarithmic scale on the $y$ axes in all panels and the changing scale with latitudinal bin.

ATom and extended well above the MBL into the free troposphere (Fig. 12 in black). $\mathrm{O}_{3}$ mixing ratios were highest in the tropospheric column during springtime in both hemispheres, and over both oceans (Fig. 12 in gold). A notable exception occurred during springtime in the high latitudes of the $\mathrm{NH}$, where several $\mathrm{O}_{3}$ depletion events were sampled in the lower legs of the Arctic transit. During these events, $\mathrm{O}_{3}$ mixing ratios lower than $10 \mathrm{ppbv}$ were measured, resulting in a lower 25 th percentile of the $\mathrm{O}_{3}$ distribution at the lowest altitude compared with the other seasons (Fig. 12e and o in gold). A tropospheric $\mathrm{O}_{3}$ springtime maximum has often been reported in the NH (e.g., Monks, 2000) when meteorology favors efficient transport of $\mathrm{O}_{3}$ and precursors from continental air from North America and Eurasia (Owen et al., 2006; Zhang et al., 2017, 2008). Another contributing factor is the increased frequency of stratospheric air mixing in spring that significantly contributes to higher $\mathrm{O}_{3}$ levels (Lin et al., 2015a; Tarasick et al., 2019a). Further, the tropospheric $\mathrm{O}_{3}$ springtime maximum in the $\mathrm{SH}$ is often attributed to $\mathrm{BB}$ emissions reaching a peak (Fishman et al., 1991; Gaudel et al., 2018), but stratospheric air mixing also occurs (Diab et al., 1996, 2004; Greenslade et al., 2017). Here, the $\mathrm{O}_{3}-\mathrm{CO}$ 
relationship in spring shows that the enhanced stratospheric mixing with tropospheric air during this season, both in the northern and southern middle and high latitudes, contributes to the increase in column $\mathrm{O}_{3}$ (Fig. 13). Fall and winter seasons shared similar features in the middle and high latitudes: no strong $\mathrm{O}_{3}$ gradient was measured in the free troposphere, and $\mathrm{O}_{3}$ values varied over similar ranges - about $40 \mathrm{ppbv}$ in the $\mathrm{NH}$ and about $30 \mathrm{ppbv}$ in the $\mathrm{SH}$ - during the two seasons (Fig. 12 in red and blue).

\subsection{3 $O_{3}$ enhancements}

The linear increase of $\mathrm{O}_{3}$ with $\mathrm{CO}>100$ ppbv highlights the contribution of natural and anthropogenic pollution plumes lofted from continental areas into the remote troposphere. In the $\mathrm{NH}$, these events occur almost year-round (Fig. 13b-c and $\mathrm{g}-\mathrm{h}$ ). Higher $\mathrm{CO}$ enhancements in the Pacific (Fig. 13gh) than in the Atlantic (Fig. 13b-c) have been observed before and have been attributed to sampling bias (Clark et al., 2015). Here, our findings suggest a year-round influence of continental emissions on the Pacific atmosphere despite its remoteness. Modeled back trajectories show that most air masses sampled in the NH during ATom were influenced by long-range transport of continental emissions from Asia, Africa, and North America (Fig. S6). Previous studies have shown that anthropogenic and $\mathrm{BB}$ emission outflow from Asia significantly contributed to $\mathrm{O}_{3}$ pollution events measured over the northern Pacific or in California (e.g., Heald et al., 2003; Jaffe et al., 2004; Lin et al., 2017). Intercontinental transport of anthropogenic emissions from Europe can also contribute to the Asian outflow of anthropogenic pollution (e.g., Bey et al., 2001; Liu et al., 2002; Newell and Evans, 2000). Finally, $\mathrm{O}_{3}$ enhancements in the northern Atlantic have frequently been observed and have been attributed to midlatitude anthropogenic and boreal forest fire emissions (e.g., Honrath et al., 2004; Martín et al., 2006; Trickl et al., 2003). In the SH, polluted air is encountered more often in spring and summer over the Atlantic, but springtime $\mathrm{CO}$ is greater than in other seasons over the Pacific (Fig. 13d-e and $\mathrm{i}-\mathrm{j}$ ). During spring, median $\mathrm{O}_{3}$ above $50 \mathrm{ppbv}$ was measured throughout the free troposphere in the southern midlatitudes (Fig. 12). Several air masses intercepted during these flights originated from regions that were intensively burning at the time, notably equatorial and southern Africa, Australia, and southern South America, contributing to the observed enhanced $\mathrm{O}_{3}$ and $\mathrm{CO}$ (Fig. S4). Our results expand on previous observation-based but more spatially and temporally limited studies that highlighted co-located enhancements of $\mathrm{O}_{3}$ and $\mathrm{CO}$ at remote locations to show in situ evidence of the frequent, large-scale influence of continental outflow on $\mathrm{O}_{3}$ in the remote troposphere in both oceans, as well as at almost all latitudes.

\section{Conclusions}

We present tropospheric $\mathrm{O}_{3}$ distributions measured over remote regions of the Pacific and Atlantic oceans during two airborne chemical sampling projects: the four deployments of ATom (2016-2018) and the five deployments of HIPPO (2009-2011). The data highlight several regional- and largescale features of $\mathrm{O}_{3}$ distributions and provide insight into current $\mathrm{O}_{3}$ distributions in remote regions. The main findings are as follows:

ATom and HIPPO provide a unique perspective on vertically resolved global baseline $\mathrm{O}_{3}$ distributions over the $\mathrm{Pa}$ cific and Atlantic basins and expand upon spatially limited $\mathrm{O}_{3}$ climatologies from long-term datasets to highlight largescale features necessary for model output and satellite retrieval validation.

ATom and HIPPO $\mathrm{O}_{3}$ data are consistent - where they overlap - with measurement-based climatologies of tropospheric $\mathrm{O}_{3}$ from well-established ozonesonde and commercial aircraft monitoring programs. ATom and HIPPO seasonal median $\mathrm{O}_{3}$ correlated well with corresponding seasonal median $\mathrm{O}_{3}$ from ozonesondes $\left(R^{2}>0.7\right)$, giving confidence in the accurate depiction of the emerging global $\mathrm{O}_{3}$ climatology by these diverse research activities. ATom and HIPPO captured $30 \%-71 \%$ of $\mathrm{O}_{3}$ variability measured by ozonesondes launched in the vicinity of the aircraft flight tracks and had the same mode of the $\mathrm{O}_{3}$ distribution as determined by IAGOS in the northern Atlantic UTLS. This representativeness evaluation on global scales highlights the usefulness of airborne observations to fill in the gaps of established but limited $\mathrm{O}_{3}$ climatologies. Higher $\mathrm{O}_{3}$ loading in the NH compared with the $\mathrm{SH}$ is consistent with the heterogeneous distribution of $\mathrm{O}_{3}$ precursor emissions around the globe, mostly concentrated in the $\mathrm{NH}$, which is a result consistent with previous modeling studies and satellite observations. ATom Atlantic vs. Pacific comparison reveals a similar $\mathrm{O}_{3}$ distribution in the free troposphere up to $\sim 8 \mathrm{~km}$ in the middle and high latitudes, but not in the tropics. Similar $\mathrm{O}_{3}$ distributions across latitude bands have been suggested in the past, but these studies were limited to the northern midlatitudes. Conversely, other satellite, modeling, and observation-based studies indicated significant $\mathrm{O}_{3}$ longitudinal gradients. Here, our findings are consistent with zonal transport smoothing the baseline $\mathrm{O}_{3}$ distribution longitudinally from the Pacific to the Atlantic. In the tropics, median $\mathrm{O}_{3}$ mixing ratios are about twice as high in the Atlantic as in the Pacific, due to a well-documented mixture of dynamical patterns interacting with the transport of continental air masses.

A comparison of seasonal $\mathrm{O}_{3}$ vertical profiles did not reveal a marked seasonality in the tropics but instead highlighted the influence of specific events, most notably BB emissions from Africa and South America, which have been extensively documented in the literature. In the extra-tropics, the summer season was characterized by a steeper tropo- 
spheric $\mathrm{O}_{3}$ gradient driven by a very low $\mathrm{O}_{3}$ abundance in the MBL. Fall and winter seasons generally led to near-constant $\mathrm{O}_{3}$ mixing ratios from the surface to the upper troposphere, while the highest $\mathrm{O}_{3}$ abundance was recorded during the spring season when more frequent and intense stratospheric intrusions and transport of air masses from continental regions occur. ATom and HIPPO provide the first airborne in situ vertically resolved $\mathrm{O}_{3}$ climatology covering both the Atlantic and Pacific oceans in the NH and in the SH. They confirm and extend the current understanding of $\mathrm{O}_{3}$ variability in the remote troposphere, built over several decades by airborne campaigns, monitoring networks, and satellite observations.

Overall, this paper highlights the value of the ATom and HIPPO datasets, which cover spatial scales commensurate with the grid resolution of current Earth system models and are also useful as a priori estimates for improved retrievals of tropospheric $\mathrm{O}_{3}$ from satellite remote sensing platforms. In addition, ATom and HIPPO in situ measurements help to establish the quantitative legacy of global pollution transport and chemistry through the evaluation of key, covarying species - in this case $\mathrm{O}_{3}$ and $\mathrm{CO}$, and reveal the year-round pervasive influence of continental outflow on $\mathrm{O}_{3}$ enhancements in the remote troposphere. ATom and HIPPO datasets should be critical for improving the scientific community's understanding of $\mathrm{O}_{3}$ production and loss processes as well as the influence of anthropogenic emissions on baseline $\mathrm{O}_{3}$ in remote regions. They provide a timely addition to the Tropospheric Ozone Assessment Report (TOAR) effort to characterize the global-scale $\mathrm{O}_{3}$ distribution and address some of the measurement gaps identified therein.

Data availability. ATom data can be obtained from the ATom data repository at the NASA/ORNL DAAC: https://doi.org/10. 3334/ORNLDAAC/1581 (Wofsy et al., 2018). HIPPO data can be obtained from the HIPPO data repository at the NCAR/EOL data archive https://doi.org/10.3334/CDIAC/HIPPO_010 (Wofsy et al., 2017). IAGOS datasets were obtained from the existing MOZAIC-IAGOS database and are freely available on http://www.iagos.fr (last access: 15 January 2019) or via the AERIS web site http://www.aeris-data.fr (last access: 15 January 2019). Ozonesonde measurements are all freely accessible and are provided by the WMO/GAW Ozone Monitoring Community, World Meteorological Organization-Global Atmosphere Watch Program (WMO-GAW)/World Ozone and Ultraviolet Radiation Data Centre (WOUDC) at https://woudc.org (https://doi.org/10.14287/10000001; last access: 15 January 2019). A list of all contributors to ozonesonde measurements is available on the WOUDC website.

Supplement. The supplement related to this article is available online at: https://doi.org/10.5194/acp-20-10611-2020-supplement.
Author contributions. SCW and TBR designed the research (ATom and HIPPO). The measurements were carried out by IB, JP, CRT, TC, RC, BD, GWD, JWE, RSG, EJH, KM, FLM, CS, and TBR. BJJ, RK, RQ, RS, DWT, AMT, and JCW provided the ozonesonde measurements. HC, AG, and VT provided the IAGOS measurements. Back trajectory calculations were provided by ER and KCA. IB, JP, CRT, KCA, RC, AG, EJH, KM, DDP, RQ, ER, DWT, AMT, VT, JCW, SCW, and TBR contributed to the discussion and interpretation of the results. IB, JP, and TBR wrote the paper.

Competing interests. The authors declare that they have no conflict of interest.

Acknowledgements. We thank the ATom leadership team, the science team, and the DC-8 pilots and crew for contributions to the ATom measurements. We thank Andy Neuman, Hélène Angot, and Owen Cooper for helpful discussions and careful editing of this paper.

Financial support. ATom was funded in response to NASA ROSES-2013 NRA NNH13ZDA001N-EVS2. The HIPPO program was supported by NSF grants (grant nos. ATM-0628575, ATM0628519, and ATM-0628388). The authors acknowledge support from the U.S. National Oceanic and Atmospheric Administration (NOAA) Health of the Atmosphere and Atmospheric Chemistry, Carbon Cycle, and Climate programs. SHADOZ ozonesondes are supported by the NASA Upper Atmosphere Research program. Ozone soundings at Marambio have been supported by the Finnish Antarctic research program (FINNARP). The IAGOS program acknowledges the European Commission for its support of the MOZAIC project (1994-2003), the preparatory phase of IAGOS (2005-2013), and IGAS (2013-2016); the partner institutions of the IAGOS Research Infrastructure (FZJ, DLR, MPI, and KIT in Germany; CNRS, Météo-France, and Université Paul Sabatier in France; and the University of Manchester in the UK); the French Atmospheric Data Center AERIS for hosting the database; and the participating airlines (Lufthansa, Air France, China Airlines, Iberia, Cathay Pacific, and Hawaiian Airlines) for transporting the instrumentation free of charge.

Review statement. This paper was edited by Hang Su and reviewed by two anonymous referees.

\section{References}

Andreae, M. O., Anderson, B. E., Blake, D. R., Bradshaw, J. D., Collins, J. E., Gregory, G. L., Sachse, G. W., and Shipham, M. C.: Influence of plumes from biomass burning on atmospheric chemistry over the equatorial and tropical South Atlantic during CITE 3, J. Geophys. Res., 99, 12793, https://doi.org/10.1029/94JD00263, 1994.

Bey, I., Jacob, D. J., Logan, J. A., and Yantosca, R. M.: Asian chemical outflow to the Pacific in spring: Origins, pathways, 
and budgets, J. Geophys. Res.-Atmos., 106, 23097-23113, https://doi.org/10.1029/2001JD000806, 2001.

Bowman, K. P.: Large-scale isentropic mixing properties of the Antarctic polar vortex from analyzed winds, J. Geophys. Res.Atmos., 98, 23013-23027, https://doi.org/10.1029/93JD02599, 1993.

Bowman, K. P. and Carrie, G. D.: The Mean-Meridional Transport Circulation of the Troposphere in an Idealized GCM, J. Atmos. Sci., 59, 1502-1514, https://doi.org/10.1175/15200469(2002)059<1502:TMMTCO>2.0.CO;2, 2002.

Brenninkmeijer, C. A. M., Crutzen, P., Boumard, F., Dauer, T., Dix, B., Ebinghaus, R., Filippi, D., Fischer, H., Franke, H., Frieß, U., Heintzenberg, J., Helleis, F., Hermann, M., Kock, H. H., Koeppel, C., Lelieveld, J., Leuenberger, M., Martinsson, B. G., Miemczyk, S., Moret, H. P., Nguyen, H. N., Nyfeler, P., Oram, D., O'Sullivan, D., Penkett, S., Platt, U., Pupek, M., Ramonet, M., Randa, B., Reichelt, M., Rhee, T. S., Rohwer, J., Rosenfeld, K., Scharffe, D., Schlager, H., Schumann, U., Slemr, F., Sprung, D., Stock, P., Thaler, R., Valentino, F., Velthoven, P. van, Waibel, A., Wandel, A., Waschitschek, K., Wiedensohler, A., Xueref-Remy, I., Zahn, A., Zech, U., and Ziereis, H.: Civil Aircraft for the regular investigation of the atmosphere based on an instrumented container: The new CARIBIC system, Atmos. Chem. Phys., 7, 4953-4976, https://doi.org/10.5194/acp-7-4953-2007, 2007.

Browell, E. V., Fenn, M. A., Butler, C. F., Grant, W. B., Merrill, J. T., Newell, R. E., Bradshaw, J. D., Sandholm, S. T., Anderson, B. E., Bandy, A. R., Bachmeier, A. S., Blake, D. R., Davis, D. D., Gregory, G. L., Heikes, B. G., Kondo, Y., Liu, S. C., Rowland, F. S., Sachse, G. W., Singh, H. B., Talbot, R. W., and Thornton, D. C.: Large-scale air mass characteristics observed over western Pacific during summertime, J. Geophys. Res.-Atmos., 101, 1691-1712, https://doi.org/10.1029/95JD02200, 1996a.

Browell, E. V., Fenn, M. A., Butler, C. F., Grant, W. B., Clayton, M. B., Fishman, J., Bachmeier, A. S., Anderson, B. E., Gregory, G. L., Fuelberg, H. E., Bradshaw, J. D., Sandholm, S. T., Blake, D. R., Heikes, B. G., Sachse, G. W., Singh, H. B., and Talbot, R. W.: Ozone and aerosol distributions and air mass characteristics over the South Atlantic Basin during the burning season, J. Geophys. Res.-Atmos., 101, 24043-24068, https://doi.org/10.1029/95JD02536, 1996b.

Clark, H., Sauvage, B., Thouret, V., Nédélec, P., Blot, R., Wang, K.-Y., Smit, H., Neis, P., Petzold, A., Athier, G., Boulanger, D., Cousin, J.-M., Beswick, K., Gallagher, M., Baumgardner, D., Kaiser, J., Flaud, J.-M., Wahner, A., Volz-Thomas, A., and Cammas, J.-P.: The first regular measurements of ozone, carbon monoxide and water vapour in the Pacific UTLS by IAGOS, Tellus B, 67, 28385, https://doi.org/10.3402/tellusb.v67.28385, 2015

Cohen, Y., Petetin, H., Thouret, V., Marécal, V., Josse, B., Clark, H., Sauvage, B., Fontaine, A., Athier, G., Blot, R., Boulanger, D., Cousin, J.-M., and Nédélec, P.: Climatology and long-term evolution of ozone and carbon monoxide in the upper tropospherelower stratosphere (UTLS) at northern midlatitudes, as seen by IAGOS from 1995 to 2013, Atmos. Chem. Phys., 18, 5415-5453, https://doi.org/10.5194/acp-18-5415-2018, 2018.

Cooper, O. R., Stohl, A., Hübler, G., Hsie, E. Y., Parrish, D. D., Tuck, A. F., Kiladis, G. N., Oltmans, S. J., Johnson, B. J., Shapiro, M., Moody, J. L., and Lefohn, A. S.: Direct transport of midlatitude stratospheric ozone into the lower troposphere and marine boundary layer of the tropical Pacific Ocean, J. Geophys. Res., 110, D23310, https://doi.org/10.1029/2005JD005783, 2005.

Cooper, O. R., Parrish, D. D., Ziemke, J., Balashov, N. V., Cupeiro, M., Galbally, I. E., Gilge, S., Horowitz, L., Jensen, N. R., Lamarque, J.-F., Naik, V., Oltmans, S. J., Schwab, J., Shindell, D. T., Thompson, A. M., Thouret, V., Wang, Y., and Zbinden, R. M.: Global distribution and trends of tropospheric ozone: An observation-based review, Elem. Sci. Anth., 2, 000029, https://doi.org/10.12952/journal.elementa.000029, 2014.

Crawford, J., Davis, D., Chen, G., Bradshaw, J., Sandholm, S., Kondo, Y., Liu, S., Browell, E., Gregory, G., Anderson, B., Sachse, G., Collins, J., Barrick, J., Blake, D., Talbot, R., and Singh, H.: An assessment of ozone photochemistry in the extratropical western North Pacific: Impact of continental outflow during the late winter/early spring, J. Geophys. Res.-Atmos., 102, 28469-28487, 1997.

Crutzen, P. J.: Photochemical reactions initiated by and influencing ozone in unpolluted tropospheric air, Tellus, 26, 47-57, https://doi.org/10.3402/tellusa.v26i1-2.9736, 1974.

Davis, D. D., Crawford, J., Chen, G., Chameides, W., Liu, S., Bradshaw, J., Sandholm, S., Sachse, G., Gregory, G., Anderson, B., Barrick, J., Bachmeier, A., Collins, J., Browell, E., Blake, D., Rowland, S., Kondo, Y., Singh, H., Talbot, R., Heikes, B., Merrill, J., Rodriguez, J., and Newell, R. E.: Assessment of ozone photochemistry in the western North Pacific as inferred from PEM-West A observations during the fall 1991, J. Geophys. Res.Atmos., 101, 2111-2134, https://doi.org/10.1029/95JD02755, 1996.

Derwent, R. G., Parrish, D. D., Galbally, I. E., Stevenson, D. S., Doherty, R. M., Young, P. J., and Shallcross, D. E.: Interhemispheric differences in seasonal cycles of tropospheric ozone in the marine boundary layer: Observation-model comparisons, J. Geophys. Res.-Atmos., 121, 11075-11085, https://doi.org/10.1002/2016JD024836, 2016.

Diab, R. D., Thompson, A. M., Zunckel, M., Coetzee, G. J. R., Combrink, J., Bodeker, G. E., Fishman, J., Sokolic, F., McNamara, D. P., Archer, C. B., and Nganga, D.: Vertical ozone distribution over southern Africa and adjacent oceans during SAFARI-92, J. Geophys. Res.-Atmos., 101, 23823-23833, https://doi.org/10.1029/96JD01267, 1996.

Diab, R. D., Thompson, A. M., Mari, K., Ramsay, L., and Coetzee, G. J. R.: Tropospheric ozone climatology over Irene, South Africa, from 1990 to 1994 and 1998 to 2002, J. Geophys. Res.Atmos., 109, D20301, https://doi.org/10.1029/2004JD004793, 2004.

Edwards, D. P., Lamarque, J.-F., Attié, J.-L., Emmons, L. K., Richter, A., Cammas, J.-P., Gille, J. C., Francis, G. L., Deeter, M. N., Warner, J., Ziskin, D. C., Lyjak, L. V., Drummond, J. R., and Burrows, J. P.: Tropospheric ozone over the tropical Atlantic: A satellite perspective, J. Geophys. Res.-Atmos., 108, 4237, https://doi.org/10.1029/2002JD002927, 2003.

Fan, S.-M. and Jacob, D. J.: Surface ozone depletion in Arctic spring sustained by bromine reactions on aerosols, Nature, 359 , 522-524, https://doi.org/10.1038/359522a0, 1992.

Fenn, M. A., Browell, E. V., Butler, C. F., Grant, W. B., Kooi, S. A., Clayton, M. B., Gregory, G. L., Newell, R. E., Zhu, Y., Dibb, J. E., Fuelberg, H. E., Anderson, B. E., Bandy, A. R., Blake, D. R., Bradshaw, J. D., Heikes, B. G., Sachse, G. W., Sandholm, S. 
T., Singh, H. B., Talbot, R. W., and Thornton, D. C.: Ozone and aerosol distributions and air mass characteristics over the South Pacific during the burning season, J. Geophys. Res.-Atmos., 104, 16197-16212, https://doi.org/10.1029/1999JD900065, 1999.

Fishman, J., Watson, C. E., Larsen, J. C., and Logan, J. A.: Distribution of tropospheric ozone determined from satellite data, J. Geophys. Res.-Atmos., 95, 3599-3617, https://doi.org/10.1029/JD095iD04p03599, 1990.

Fishman, J., Fakhruzzaman, K., Cros, B., and Nganga, D.: Identification of Widespread Pollution in the Southern Hemisphere Deduced from Satellite Analyses, Science, 252, 1693-1696, https://doi.org/10.1126/science.252.5013.1693, 1991.

Fishman, J., Hoell, J. M., Bendura, R. D., McNeal, R. J., and Kirchhoff, V. W. J. H.: NASA GTE TRACE A experiment (September-October 1992): Overview, J. Geophys. Res.-Atmos., 101, 23865-23879, https://doi.org/10.1029/96JD00123, 1996.

Gaudel, A., Clark, H., Thouret, V., Jones, L., Inness, A., Flemming, J., Stein, O., Huijnen, V., Eskes, H., Nedelec, P., and Boulanger, D.: On the use of MOZAIC-IAGOS data to assess the ability of the MACC reanalysis to reproduce the distribution of ozone and CO in the UTLS over Europe, Tellus B, 68, 27955, https://doi.org/10.3402/tellusb.v67.27955, 2015.

Gaudel, A., Cooper, O. R., Ancellet, G., Barret, B., Boynard, A., Burrows, J. P., Clerbaux, C., Coheur, P.-F., Cuesta, J., Cuevas, E., Doniki, S., Dufour, G., Ebojie, F., Foret, G., Garcia, O., Muños, M. J. G., Hannigan, J. W., Hase, F., Huang, G., Hassler, B., Hurtmans, D., Jaffe, D., Jones, N., Kalabokas, P., Kerridge, B., Kulawik, S. S., Latter, B., Leblanc, T., Flochmoën, E. L., Lin, W., Liu, J., Liu, X., Mahieu, E., McClure-Begley, A., Neu, J. L., Osman, M., Palm, M., Petetin, H., Petropavlovskikh, I., Querel, R., Rahpoe, N., Rozanov, A., Schultz, M. G., Schwab, J., Siddans, R., Smale, D., Steinbacher, M., Tanimoto, H., Tarasick, D. W., Thouret, V., Thompson, A. M., Trickl, T., Weatherhead, E., Wespes, C., Worden, H. M., Vigouroux, C., Xu, X., Zeng, G., and Ziemke, J.: Tropospheric Ozone Assessment Report: Present-day distribution and trends of tropospheric ozone relevant to climate and global atmospheric chemistry model evaluation, Elem. Sci. Anth., 6, p. 39, https://doi.org/10.1525/elementa.291, 2018.

Greenslade, J. W., Alexander, S. P., Schofield, R., Fisher, J. A., and Klekociuk, A. K.: Stratospheric ozone intrusion events and their impacts on tropospheric ozone in the Southern Hemisphere, Atmos. Chem. Phys., 17, 10269-10290, https://doi.org/10.5194/acp-17-10269-2017, 2017.

Heald, C. L., Jacob, D. J., Fiore, A. M., Emmons, L. K., Gille, J. C., Deeter, M. N., Warner, J., Edwards, D. P., Crawford, J. H., Hamlin, A. J., Sachse, G. W., Browell, E. V., Avery, M. A., Vay, S. A., Westberg, D. J., Blake, D. R., Singh, H. B., Sandholm, S. T., Talbot, R. W., and Fuelberg, H. E.: Asian outflow and transPacific transport of carbon monoxide and ozone pollution: An integrated satellite, aircraft, and model perspective, J. Geophys. Res.-Atmos., 108, 4804, https://doi.org/10.1029/2003JD003507, 2003.

Holmes, C. D., Prather, M. J., Søvde, O. A., and Myhre, G.: Future methane, hydroxyl, and their uncertainties: key climate and emission parameters for future predictions, Atmos. Chem. Phys., 13, 285-302, https://doi.org/10.5194/acp-13-285-2013, 2013.

Honrath, R. E., Owen, R. C., Martín, M. V., Reid, J. S., Lapina, K., Fialho, P., Dziobak, M. P., Kleissl, J., and Westphal, D. L.: Regional and hemispheric impacts of anthropogenic and biomass burning emissions on summertime $\mathrm{CO}$ and $\mathrm{O}_{3}$ in the North Atlantic lower free troposphere, J. Geophys. Res.-Atmos., 109, D24310, https://doi.org/10.1029/2004JD005147, 2004.

Hu, L., Jacob, D. J., Liu, X., Zhang, Y., Zhang, L., Kim, P. S., Sulprizio, M. P., and Yantosca, R. M.: Global budget of tropospheric ozone: Evaluating recent model advances with satellite (OMI), aircraft (IAGOS), and ozonesonde observations, Atmos. Environ., 167, 323-334, https://doi.org/10.1016/j.atmosenv.2017.08.036, 2017.

IPCC: Climate Change 2013: The Physical Science Basis. Contribution of Working Group I to the Fifth Assessment Report of the Intergovernmental Panel on Climate Change, Cambridge University Press, Cambridge, United Kingdom and New York, NY, USA, available at: https://www.ipcc.ch/report/ar5/wg1/ (last access: 8 January 2019), 2013.

Jacob, D. J., Heikes, E. G., Fan, S.-M., Logan, J. A., Mauzerall, D. L., Bradshaw, J. D., Singh, H. B., Gregory, G. L., Talbot, R. W., Blake, D. R., and Sachse, G. W.: Origin of ozone and NOx in the tropical troposphere: A photochemical analysis of aircraft observations over the South Atlantic basin, J. Geophys. Res.-Atmos., 101, 24235-24250, https://doi.org/10.1029/96JD00336, 1996.

Jaffe, D., Bertschi, I., Jaeglé, L., Novelli, P., Reid, J. S., Tanimoto, H., Vingarzan, R., and Westphal, D. L.: Long-range transport of Siberian biomass burning emissions and impact on surface ozone in western North America, Geophys. Res. Lett., 31, L16106, https://doi.org/10.1029/2004GL020093, 2004.

Jensen, A. A., Thompson, A. M., and Schmidlin, F. J.: Classification of Ascension Island and Natal ozonesondes using self-organizing maps, J. Geophys. Res.-Atmos., 117, D04302, https://doi.org/10.1029/2011JD016573, 2012.

Jourdain, L., Worden, H. M., Worden, J. R., Bowman, K., Li, Q., Eldering, A., Kulawik, S. S., Osterman, G., Boersma, K. F., Fisher, B., Rinsland, C. P., Beer, R., and Gunson, M.: Tropospheric vertical distribution of tropical Atlantic ozone observed by TES during the northern African biomass burning season, Geophys. Res. Lett., 34, L04810, https://doi.org/10.1029/2006GL028284, 2007.

Junge, C. E.: Global ozone budget and exchange between stratosphere and troposphere, Tellus, 14, 363-377, https://doi.org/10.1111/j.2153-3490.1962.tb01349.x, 1962.

Katich, J. M., Samset, B. H., Bui, T. P., Dollner, M., Froyd, K. D., Campuzano-Jost, P., Nault, B. A., Schroder, J. C., Weinzierl, B., and Schwarz, J. P.: Strong Contrast in Remote Black Carbon Aerosol Loadings Between the Atlantic and Pacific Basins, J. Geophys. Res.-Atmos., 123, 13386-13395, https://doi.org/10.1029/2018JD029206, 2018.

Kley, D., Crutzen, P. J., Smit, H. G. J., Vömel, H., Oltmans, S. J., Grassl, H., and Ramanathan, V.: Observations of Near-Zero Ozone Concentrations Over the Convective Pacific: Effects on Air Chemistry, Science, 274, 230-233, https://doi.org/10.1126/science.274.5285.230, 1996.

Komhyr, W.: Electrochemical Concentration Cells for Gas Analysis, Ann. Geophys., 25, 203-210, 1969.

Kondo, Y., Morino, Y., Takegawa, N., Koike, M., Kita, K., Miyazaki, Y., Sachse, G. W., Vay, S. A., Avery, M. A., Flocke, F., Weinheimer, A. J., Eisele, F. L., Zondlo, M. A., Weber, R. J., Singh, H. B., Chen, G., Crawford, J., Blake, D. R., Fuelberg, H. E., Clarke, A. D., Talbot, R. W., Sandholm, S. T., Browell, E. V., Streets, D. G., and Liley, B.: Impacts of biomass burning in Southeast Asia on ozone and reactive nitrogen over the west- 
ern Pacific in spring, J. Geophys. Res.-Atmos., 109, D15S12, https://doi.org/10.1029/2003JD004203, 2004.

Krishnamurti, T. N., Sinha, M. C., Kanamitsu, M., Oosterhof, D., Fuelberg, H., Chatfield, R., Jacob, D. J., and Logan, J.: Passive tracer transport relevant to the TRACE A experiment, J. Geophys. Res.-Atmos., 101, 23889-23907, https://doi.org/10.1029/95JD02419, 1996.

Leonard, M., Petropavlovskikh, I., Lin, M., McClure-Begley, A., Johnson, B. J., Oltmans, S. J., and Tarasick, D.: An assessment of 10-year NOAA aircraft-based tropospheric ozone profiling in Colorado, Atmos. Environ., 158, 116-127, https://doi.org/10.1016/j.atmosenv.2017.03.013, 2017.

Levy, H.: Normal Atmosphere: Large Radical and Formaldehyde Concentrations Predicted, Science, 173, 141-143, https://doi.org/10.1126/science.173.3992.141, 1971.

Lin, M., Fiore, A. M., Horowitz, L. W., Langford, A. O., Oltmans, S. J., Tarasick, D., and Rieder, H. E.: Climate variability modulates western US ozone air quality in spring via deep stratospheric intrusions, Nat. Commun., 6, 7105, https://doi.org/10.1038/ncomms8105, 2015a.

Lin, M., Horowitz, L. W., Cooper, O. R., Tarasick, D. W., Conley, S., Iraci, L. T., Johnson, B. J., Leblanc, T., Petropavlovskikh, I., and Yates, E. L.: Revisiting the evidence of increasing springtime ozone mixing ratios in the free troposphere over western North America, Geophys. Res. Lett., 42, 8719-8728, https://doi.org/10.1002/2015GL065311, 2015b.

Lin, M., Horowitz, L. W., Payton, R., Fiore, A. M., and Tonnesen, G.: US surface ozone trends and extremes from 1980 to 2014: quantifying the roles of rising Asian emissions, domestic controls, wildfires, and climate, Atmos. Chem. Phys., 17, 29432970, https://doi.org/10.5194/acp-17-2943-2017, 2017.

Liu, G., Tarasick, D. W., Fioletov, V. E., Sioris, C. E., and Rochon, Y. J.: Ozone correlation lengths and measurement uncertainties from analysis of historical ozonesonde data in North America and Europe, J. Geophys. Res.-Atmos., 114, D04112, https://doi.org/10.1029/2008JD010576, 2009.

Liu, G., Liu, J., Tarasick, D. W., Fioletov, V. E., Jin, J. J., Moeini, O., Liu, X., Sioris, C. E., and Osman, M.: A global tropospheric ozone climatology from trajectory-mapped ozone soundings, Atmos. Chem. Phys., 13, 10659-10675, https://doi.org/10.5194/acp-13-10659-2013, 2013.

Liu, H., Jacob, D. J., Chan, L. Y., Oltmans, S. J., Bey, I., Yantosca, R. M., Harris, J. M., Duncan, B. N., and Martin, R. V.: Sources of tropospheric ozone along the Asian Pacific Rim: An analysis of ozonesonde observations, J. Geophys. Res.-Atmos., 107, 4573, https://doi.org/10.1029/2001JD002005, 2002.

Logan, J. A.: Tropospheric ozone: Seasonal behavior, trends, and anthropogenic influence, J. Geophys. Res.-Atmos., 90, 1046310482, https://doi.org/10.1029/JD090iD06p10463, 1985.

Logan, J. A. and Kirchhoff, V. W. J. H.: Seasonal variations of tropospheric ozone at Natal, Brazil, J. Geophys. Res.-Atmos., 91, 7875-7881, https://doi.org/10.1029/JD091iD07p07875, 1986.

Logan, J. A., Staehelin, J., Megretskaia, I. A., Cammas, J. -P., Thouret, Claude, H., Backer, H., Steinbacher, M., Scheel, H. -E., Stübi, R., Fröhlich, M., and Derwent, R.: Changes in ozone over Europe: Analysis of ozone measurements from sondes, regular aircraft (MOZAIC) and alpine surface sites, J. Geophys. Res.Atmos., 117, D09301, https://doi.org/10.1029/2011JD016952, 2012.
Marenco, A., Thouret, V., Nédélec, P., Smit, H., Helten, M., Kley, D., Karcher, F., Simon, P., Law, K., Pyle, J., Poschmann, G., Wrede, R. V., Hume, C., and Cook, T.: Measurement of ozone and water vapor by Airbus in-service aircraft: The MOZAIC airborne program, an overview, J. Geophys. Res.-Atmos., 103, 25631-25642, https://doi.org/10.1029/98JD00977, 1998.

Martin, B. D., Fuelberg, H. E., Blake, N. J., Crawford, J. H., Logan, J. A., Blake, D. R., and Sachse, G. W.: Long-range transport of Asian outflow to the equatorial Pacific, J. Geophys. Res.-Atmos., 107, 8322, https://doi.org/10.1029/2001JD001418, 2002.

Martín, M. V., Honrath, R. E., Owen, R. C., Pfister, G., Fialho, P., and Barata, F.: Significant enhancements of nitrogen oxides, black carbon, and ozone in the North Atlantic lower free troposphere resulting from North American boreal wildfires, J. Geophys. Res.-Atmos., 111, D23S60, https://doi.org/10.1029/2006JD007530, 2006.

Mauzerall, D. L., Logan, J. A., Jacob, D. J., Anderson, B. E., Blake, D. R., Bradshaw, J. D., Heikes, B., Sachse, G. W., Singh, H., and Talbot, B.: Photochemistry in biomass burning plumes and implications for tropospheric ozone over the tropical South Atlantic, J. Geophys. Res.-Atmos., 103, 8401-8423, https://doi.org/10.1029/97JD02612, 1998.

Monks, P. S.: A review of the observations and origins of the spring ozone maximum, Atmos. Environ., 34, 3545-3561, https://doi.org/10.1016/S1352-2310(00)00129-1, 2000.

Monks, P. S., Carpenter, L. J., Penkett, S. A., Ayers, G. P., Gillett, R. W., Galbally, I. E., and (Mick) Meyer, C. P.: Fundamental ozone photochemistry in the remote marine boundary layer: the soapex experiment, measurement and theory, Atmos. Environ., 32, 3647-3664, https://doi.org/10.1016/S1352-2310(98)000843, 1998.

Monks, P. S., Salisbury, G., Holland, G., Penkett, S. A., and Ayers, G. P.: A seasonal comparison of ozone photochemistry in the remote marine boundary layer, Atmos. Environ., 34, 2547-2561, https://doi.org/10.1016/S1352-2310(99)00504-X, 2000.

Monks, P. S., Granier, C., Fuzzi, S., Stohl, A., Williams, M. L., Akimoto, H., Amann, M., Baklanov, A., Baltensperger, U., Bey, I., Blake, N., Blake, R. S., Carslaw, K., Cooper, O. R., Dentener, F., Fowler, D., Fragkou, E., Frost, G. J., Generoso, S., Ginoux, P., Grewe, V., Guenther, A., Hansson, H. C., Henne, S., Hjorth, J., Hofzumahaus, A., Huntrieser, H., Isaksen, I. S. A., Jenkin, M. E., Kaiser, J., Kanakidou, M., Klimont, Z., Kulmala, M., Laj, P., Lawrence, M. G., Lee, J. D., Liousse, C., Maione, M., McFiggans, G., Metzger, A., Mieville, A., Moussiopoulos, N., Orlando, J. J., O'Dowd, C. D., Palmer, P. I., Parrish, D. D., Petzold, A., Platt, U., Pöschl, U., Prévôt, A. S. H., Reeves, C. E., Reimann, S., Rudich, Y., Sellegri, K., Steinbrecher, R., Simpson, D., ten Brink, H., Theloke, J., van der Werf, G. R., Vautard, R., Vestreng, V., Vlachokostas, C., and von Glasow, R.: Atmospheric composition change - global and regional air quality, Atmos. Environ., 43, 5268-5350, https://doi.org/10.1016/j.atmosenv.2009.08.021, 2009.

Moxim, W. J. and Levy, H.: A model analysis of the tropical South Atlantic Ocean tropospheric ozone maximum: The interaction of transport and chemistry, J. Geophys. Res.-Atmos., 105, 17393 17415, https://doi.org/10.1029/2000JD900175, 2000.

Nath, D., Chen, W., Graf, H.-F., Lan, X., Gong, H., Nath, R., Hu, K., and Wang, L.: Subtropical Potential Vorticity Intrusion Drives 
Increasing Tropospheric Ozone over the Tropical Central Pacific, Sci. Rep., 6, 21370, https://doi.org/10.1038/srep21370, 2016.

Nédélec, P., Cammas, J.-P., Thouret, V., Athier, G., Cousin, J.-M., Legrand, C., Abonnel, C., Lecoeur, F., Cayez, G., and Marizy, C.: An improved infrared carbon monoxide analyser for routine measurements aboard commercial Airbus aircraft: technical validation and first scientific results of the MOZAIC III programme, Atmos. Chem. Phys., 3, 1551-1564, https://doi.org/10.5194/acp3-1551-2003, 2003.

Nédélec, P., Blot, R., Boulanger, D., Athier, G., Cousin, J.-M., Gautron, B., Petzold, A., Volz-Thomas, A., and Thouret, V.: Instrumentation on commercial aircraft for monitoring the atmospheric composition on a global scale: the IAGOS system, technical overview of ozone and carbon monoxide measurements, Tellus B, 68, 27791, https://doi.org/10.3402/tellusb.v67.27791, 2015.

Neuman, J. A., Trainer, M., Aikin, K. C., Angevine, W. M., Brioude, J., Brown, S. S., de Gouw, J. A., Dube, W. P., Flynn, J. H., Graus, M., Holloway, J. S., Lefer, B. L., Nedelec, P., Nowak, J. B., Parrish, D. D., Pollack, I. B., Roberts, J. M., Ryerson, T. B., Smit, H., Thouret, V., and Wagner, N. L.: Observations of ozone transport from the free troposphere to the Los Angeles basin, J. Geophys. Res.-Atmos., 117, D00V09, https://doi.org/10.1029/2011JD016919, 2012.

Newell, R. E. and Evans, M. J.: Seasonal changes in pollutant transport to the North Pacific: The relative importance of Asian and European sources, Geophys. Res. Lett., 27, 2509-2512, https://doi.org/10.1029/2000GL011501, 2000.

Newton, R., Vaughan, G., Hintsa, E., Filus, M. T., Pan, L. L., Honomichl, S., Atlas, E., Andrews, S. J., and Carpenter, L. J.: Observations of ozone-poor air in the tropical tropopause layer, Atmos. Chem. Phys., 18, 5157-5171, https://doi.org/10.5194/acp18-5157-2018, 2018.

Oltmans, S. J., Johnson, B. J., Harris, J. M., Vömel, H., Thompson, A. M., Koshy, K., Simon, P., Bendura, R. J., Logan, J. A., Hasebe, F., Shiotani, M., Kirchhoff, V. W. J. H., Maata, M., Sami, G., Samad, A., Tabuadravu, J., Enriquez, H., Agama, M., Cornejo, J., and Paredes, F.: Ozone in the Pacific tropical troposphere from ozonesonde observations, J. Geophys. Res.-Atmos., 106, 3250332525, https://doi.org/10.1029/2000JD900834, 2001.

Oltmans, S. J., Lefohn, A. S., Shadwick, D., Harris, J. M., Scheel, H. E., Galbally, I., Tarasick, D. W., Johnson, B. J., Brunke, E.G., Claude, H., Zeng, G., Nichol, S., Schmidlin, F., Davies, J., Cuevas, E., Redondas, A., Naoe, H., Nakano, T., and Kawasato, T.: Recent tropospheric ozone changes - A pattern dominated by slow or no growth, Atmos. Environ., 67, 331-351, https://doi.org/10.1016/j.atmosenv.2012.10.057, 2013.

Owen, R. C., Cooper, O. R., Stohl, A., and Honrath, R. E.: An analysis of the mechanisms of North American pollutant transport to the central North Atlantic lower free troposphere, J. Geophys. Res.-Atmos., 111, D23S58, https://doi.org/10.1029/2006JD007062, 2006.

Pan, L. L., Honomichl, S. B., Randel, W. J., Apel, E. C., Atlas, E. L., Beaton, S. P., Bresch, J. F., Hornbrook, R., Kinnison, D. E., Lamarque, J.-F., Saiz-Lopez, A., Salawitch, R. J., and Weinheimer, A. J.: Bimodal distribution of free tropospheric ozone over the tropical western Pacific revealed by airborne observations, Geophys. Res. Lett., 42, 7844-7851, https://doi.org/10.1002/2015GL065562, 2015.
Parrish, D. D., Galbally, I. E., Lamarque, J. -F., Naik, V., Horowitz, Shindell, D. T., Oltmans, S. J., Derwent, R., Tanimoto, H., Labuschagne, C., and Cupeiro, M.: Seasonal cycles of $\mathrm{O}_{3}$ in the marine boundary layer: Observation and model simulation comparisons, J. Geophys. Res.-Atmos., 121, 538-557, https://doi.org/10.1002/2015JD024101, 2016.

Parrish, D. D., Derwent, R. G., Steinbrecht, W., Stübi, R., Malderen, R. V., Steinbacher, M., Trickl, T., Ries, L., and Xu, X.: Zonal Similarity of Long-term Changes and Seasonal Cycles of Baseline Ozone at Northern Mid-latitudes, J. Geophys. Res.-Atmos., e2019JD031908, https://doi.org/10.1029/2019JD031908, 2020.

Perkins, S. E., Pitman, A. J., Holbrook, N. J., and McAneney, J.: Evaluation of the AR4 Climate Models' Simulated Daily Maximum Temperature, Minimum Temperature, and Precipitation over Australia Using Probability Density Functions, J. Clim., 20, 4356-4376, https://doi.org/10.1175/JCLI4253.1, 2007.

Petetin, H., Thouret, V., Fontaine, A., Sauvage, B., Athier, G., Blot, R., Boulanger, D., Cousin, J.-M., and Nédélec, P.: Characterising tropospheric O3 and CO around Frankfurt over the period 19942012 based on MOZAIC-IAGOS aircraft measurements, Atmos. Chem. Phys., 16, 15147-15163, https://doi.org/10.5194/acp-1615147-2016, 2016.

Petzold, A., Thouret, V., Gerbig, C., Zahn, A., Brenninkmeijer, C. A. M., Gallagher, M., Hermann, M., Pontaud, M., Ziereis, H., Boulanger, D., Marshall, J., Nédélec, P., Smit, H. G. J., Friess, U., Flaud, J.-M., Wahner, A., Cammas, J.-P., Volz-Thomas, A., and TEAM, I.: Global-scale atmosphere monitoring by in-service aircraft - current achievements and future prospects of the European Research Infrastructure IAGOS, Tellus B, 67, 28452, https://doi.org/10.3402/tellusb.v67.28452, 2015.

Pickering, K. E., Thompson, A. M., Wang, Y., Tao, W.-K., McNamara, D. P., Kirchhoff, V. W. J. H., Heikes, B. G., Sachse, G. W., Bradshaw, J. D., Gregory, G. L., and Blake, D. R.: Convective transport of biomass burning emissions over Brazil during TRACE A, J. Geophys. Res.-Atmos., 101, 23993-24012, https://doi.org/10.1029/96JD00346, 1996.

Prather, M. J., Zhu, X., Flynn, C. M., Strode, S. A., Rodriguez, J. M., Steenrod, S. D., Liu, J., Lamarque, J.-F., Fiore, A. M., Horowitz, L. W., Mao, J., Murray, L. T., Shindell, D. T., and Wofsy, S. C.: Global atmospheric chemistry - which air matters, Atmos. Chem. Phys., 17, 9081-9102, https://doi.org/10.5194/acp-17-9081-2017, 2017.

Proffitt, M. H. and McLaughlin, R. J.: Fast-response dualbeam UV-absorption ozone photometer suitable for use on stratospheric balloons, Rev. Sci. Instrum., 54, 1719-1728, https://doi.org/10.1063/1.1137316, 1983.

Ridley, B. A., Grahek, F. E., and Walega, J. G.: A Small High-Sensitivity, Medium-Response Ozone Detector Suitable for Measurements from Light Aircraft, J. Atmos. Oceanic Technol., 9, 142-148, https://doi.org/10.1175/15200426(1992)009<0142:ASHSMR>2.0.CO;2, 1992.

Santoni, G. W., Daube, B. C., Kort, E. A., Jiménez, R., Park, S. Pittman, J. V., Gottlieb, E., Xiang, B., Zahniser, M. S., Nelson, D. D., McManus, J. B., Peischl, J., Ryerson, T. B., Holloway, J. S., Andrews, A. E., Sweeney, C., Hall, B., Hintsa, E. J., Moore, F. L., Elkins, J. W., Hurst, D. F., Stephens, B. B., Bent, J., and Wofsy, S. C.: Evaluation of the airborne quantum cascade laser spectrometer (QCLS) measurements of the carbon and greenhouse gas suite $-\mathrm{CO}_{2}, \mathrm{CH}_{4}, \mathrm{~N}_{2} \mathrm{O}$, and $\mathrm{CO}$ - during the Cal- 
Nex and HIPPO campaigns, Atmos. Meas. Tech, 7, 1509-1526, https://doi.org/10.5194/amt-7-1509-2014, 2014.

Sauvage, B., Thouret, V., Thompson, A. M., Witte, J. C., Cammas, J.-P., Nédélec, P., and Athier, G.: Enhanced view of the "tropical Atlantic ozone paradox" and "zonal wave one" from the in situ MOZAIC and SHADOZ data, J. Geophys. Res.-Atmos., 111, D01301, https://doi.org/10.1029/2005JD006241, 2006.

Schultz, M. G., Jacob, D. J., Wang, Y., Logan, J. A., Atlas, E. L., Blake, D. R., Blake, N. J., Bradshaw, J. D., Browell, E. V., Fenn, M. A., Flocke, F., Gregory, G. L., Heikes, B. G., Sachse, G. W., Sandholm, S. T., Shetter, R. E., Singh, H. B., and Talbot, R. W.: On the origin of tropospheric ozone and $\mathrm{NO}_{x}$ over the tropical South Pacific, J. Geophys. Res.-Atmos., 104, 58295843, https://doi.org/10.1029/98JD02309, 1999.

Shen, Z., Liu, J., Horowitz, L. W., Henze, D. K., Fan, S., H., L. I., Mauzerall, D. L., Lin, J.-T., and Tao, S.: Analysis of transpacific transport of black carbon during HIPPO-3: implications for black carbon aging, Atmos. Chem. Phys., 14, 6315-6327, https://doi.org/10.5194/acp-14-6315-2014, 2014.

Shindell, D., Kuylenstierna, J. C. I., Vignati, E., Dingenen, R. van, Amann, M., Klimont, Z., Anenberg, S. C., Muller, N., Janssens-Maenhout, G., Raes, F., Schwartz, J., Faluvegi, G., Pozzoli, L., Kupiainen, K., Höglund-Isaksson, L., Emberson, L., Streets, D., Ramanathan, V., Hicks, K., Oanh, N. T. K., Milly, G., Williams, M., Demkine, V., and Fowler, D.: Simultaneously Mitigating Near-Term Climate Change and Improving Human Health and Food Security, Science, 335, 183-189, https://doi.org/10.1126/science.1210026, 2012.

Singh, H. B., Herlth, D., Kolyer, R., Chatfield, R., Viezee, W., Salas, L. J., Chen, Y., Bradshaw, J. D., Sandholm, S. T., Talbot, R., Gregory, G. L., Anderson, B., Sachse, G. W., Browell, E., Bachmeier, A. S., Blake, D. R., Heikes, B., Jacob, D., and Fuelberg, H. E.: Impact of biomass burning emissions on the composition of the South Atlantic troposphere: Reactive nitrogen and ozone, J. Geophys. Res.-Atmos., 101, 24203-24219, https://doi.org/10.1029/96JD01018, 1996a.

Singh, H. B., Gregory, G. L., Anderson, B., Browell, E., Sachse, G. W., Davis, D. D., Crawford, J., Bradshaw, J. D., Talbot, R., Blake, D. R., Thornton, D., Newell, R., and Merrill, J.: Low ozone in the marine boundary layer of the tropical Pacific Ocean: Photochemical loss, chlorine atoms, and entrainment, J. Geophys. Res.Atmos., 101, 1907-1917, https://doi.org/10.1029/95JD01028, 1996 b.

Singh, H. B., Herlth, D., Kolyer, R., Salas, L., Bradshaw, J. D., Sandholm, S. T., Davis, D. D., Crawford, J., Kondo, Y., Koike, M., Talbot, R., Gregory, G. L., Sachse, G. W., Browell, E., Blake, D. R., Rowland, F. S., Newell, R., Merrill, J., Heikes, B., Liu, S. C., Crutzen, P. J., and Kanakidou, M.: Reactive nitrogen and ozone over the western Pacific: Distribution, partitioning, and sources, J. Geophys. Res., 101, 1793-1808, https://doi.org/10.1029/95JD01029, 1996c.

Solomon, S., Thompson, D. W. J., Portmann, R. W., Oltmans, S. J., and Thompson, A. M.: On the distribution and variability of ozone in the tropical upper troposphere: Implications for tropical deep convection and chemical-dynamical coupling, Geophys. Res. Lett., 32, L23813, https://doi.org/10.1029/2005GL024323, 2005

Stauffer, R. M., Thompson, A. M., and Witte, J. C.: Characterizing Global Ozonesonde Profile Variability From Surface to the UT/LS With a Clustering Technique and MERRA2 Reanalysis, J. Geophys. Res.-Atmos., 123, 6213-6229, https://doi.org/10.1029/2018JD028465, 2018.

Stedman, D. H., Daby, E. E., Stuhl, F., and Niki, H.: Analysis of Ozone and Nitric Oxide by a Chemiluminescent Method in Laboratory and Atmospheric Studies of Photochemical Smog, JAPCA J. Air Waste Ma., 22, 260-263, https://doi.org/10.1080/00022470.1972.10469635, 1972.

Tarasick, D. W. and Bottenheim, J. W.: Surface ozone depletion episodes in the Arctic and Antarctic from historical ozonesonde records, Atmos. Chem. Phys., 2, 197-205, https://doi.org/10.5194/acp-2-197-2002, 2002.

Tarasick, D. W., Jin, J. J., Fioletov, V. E., Liu, G., Thompson, A. M., Oltmans, S. J., Liu, J., Sioris, C. E., Liu, X., Cooper, O. R., Dann, T., and Thouret, V.: High-resolution tropospheric ozone fields for INTEX and ARCTAS from IONS ozonesondes, J. Geophys. Res.-Atmos., 115, D20301, https://doi.org/10.1029/2009JD012918, 2010.

Tarasick, D. W., Carey-Smith, T. K., Hocking, W. K., Moeini, O., He, H., Liu, J., Osman, M. K., Thompson, A. M., Johnson, B. J., Oltmans, S. J., and Merrill, J. T.: Quantifying stratospheretroposphere transport of ozone using balloon-borne ozonesondes, radar windprofilers and trajectory models, Atmos. Environ., 198, 496-509, https://doi.org/10.1016/j.atmosenv.2018.10.040, 2019a.

Tarasick, D. W., Galbally, I. E., Cooper, O. R., Schultz, M. G., Ancellet, G., Leblanc, T., Wallington, T. J., Ziemke, J., Liu, X., Steinbacher, M., Staehelin, J., Vigouroux, C., Hannigan, J. W., García, O., Foret, G., Zanis, P., Weatherhead, E., Petropavlovskikh, I., Worden, H., Osman, M., Liu, J., Chang, K.-L., Gaudel, A., Lin, M., Granados-Muñoz, M., Thompson, A. M., Oltmans, S. J., Cuesta, J., Dufour, G., Thouret, V., Hassler, B., Trickl, T., and Neu, J. L.: Tropospheric Ozone Assessment Report: Tropospheric ozone from 1877 to 2016, observed levels, trends and uncertainties, Elem. Sci. Anth., 7, p. 39 , https://doi.org/10.1525/elementa.376, 2019b.

Thompson, A. M., Johnson, J. E., Torres, A. L., Bates, T. S., Kelly, K. C., Atlas, E., Greenberg, J. P., Donahue, N. M., Yvon, S. A., Saltzman, E. S., Heikes, B. G., Mosher, B W., Shashkov, A. A., and Yegorov, V. I.: Ozone observations and a model of marine boundary layer photochemistry during SAGA 3, J. Geophys. Res.-Atmos., 98, 16955-16968, https://doi.org/10.1029/93JD00258, 1993.

Thompson, A. M., Pickering, K. E., McNamara, D. P., Schoeberl, M. R., Hudson, R. D., Kim, J. H., Browell, E. V., Kirchhoff, V. W. J. H., and Nganga, D.: Where did tropospheric ozone over southern Africa and the tropical Atlantic come from in October 1992? Insights from TOMS, GTE TRACE A, and SAFARI 1992, J. Geophys. Res.-Atmos., 101, 24251-24278, https://doi.org/10.1029/96JD01463, 1996.

Thompson, A. M., Doddridge, B. G., Witte, J. C., Hudson, R. D., Luke, W. T., Johnson, J. E., Johnson, B. J., Oltmans, S. J., and Weller, R.: A tropical Atlantic Paradox: Shipboard and satellite views of a tropospheric ozone maximum and wave-one in January-February 1999, Geophys. Res. Lett., 27, 3317-3320, https://doi.org/10.1029/1999GL011273, 2000.

Thompson, A. M., Miller, S. K., Tilmes, S., Kollonige, D. W., Witte, J. C., Oltmans, S. J., Johnson, B. J., Fujiwara, M., Schmidlin, F. J., Coetzee, G. J. R., Komala, N., Maata, M., Mohamad, M. 
B., Nguyo, J., Mutai, C., Ogino, S. Y., Silva, F. R. D., Leme, N. M. P., Posny, F., Scheele, R., Selkirk, H. B., Shiotani, M., Stbi, R., Levrat, G., Calpini, B., Thouret, V., Tsuruta, H., Canossa, J. V., Vmel, H., Yonemura, S., Diaz, J. A., Thanh, N. T. T., and Ha, H. T. T.: Southern Hemisphere Additional Ozonesondes (SHADOZ) ozone climatology (2005-2009): Tropospheric and tropical tropopause layer (TTL) profiles with comparisons to OMI-based ozone products, J. Geophys. Res.-Atmos., 117, D23301, https://doi.org/10.1029/2011JD016911, 2012.

Thompson, A. M., Witte, J. C., Sterling, C., Jordan, A., Johnson, B. J., Oltmans, S. J., Fujiwara, M., Vömel, H., Allaart, M., Piters, A., Coetzee, G. J. R., Posny, F., Corrales, E., Diaz, J. A., Félix, C., Komala, N., Lai, N., Ahn Nguyen, H. T., Maata, M., Mani, F., Zainal, Z., Ogino, S., Paredes, F., Penha, T. L. B., da Silva, F. R., Sallons-Mitro, S., Selkirk, H. B., Schmidlin, F. J., Stübi, R., and Thiongo, K.: First Reprocessing of Southern Hemisphere Additional Ozonesondes (SHADOZ) Ozone Profiles (1998-2016): 2. Comparisons With Satellites and Ground-Based Instruments: SHADOZ Data Evaluation, J. Geophys. Res.-Atmos., 122, 13000-13025 https://doi.org/10.1002/2017JD027406, 2017.

Thompson, A. M., Smit, H. G. J., Witte, J. C., Stauffer, R. M., Johnson, B. J., Morris, G., von der Gathen, P., Van Malderen, R., Davies, J., Piters, A., Allaart, M., Posny, F., Kivi, R., Cullis, P., Hoang Anh, N. T., Corrales, E., Machinini, T., da Silva, F. R., Paiman, G., Thiong'o, K., Zainal, Z., Brothers, G. B., Wolff, K. R., Nakano, T., Stübi, R., Romanens, G., Coetzee, G. J. R., Diaz, J. A., Mitro, S., Mohamad, M., and Ogino, S.-Y.: Ozonesonde Quality Assurance: The JOSIE-SHADOZ (2017) Experience, B. Am. Meteorol. Soc., 100, 155-171, https://doi.org/10.1175/BAMS-D-17-0311.1, 2019.

Thompson, C. R., Ryerson, T. B., Peischl, J., Barletta, B., Blake, D. R., Butler, A. H., Crounse, J. D., Evans, M. J., Fisher, J. A., Huey, L. G., Kim, M. J., Laubach, A., Moore, F. L., Ray, E. A., Murray, L. T., Sherwen, T., Strode, S. A., Wennberg, P. O., and Yu, P.: Global-scale Airborne Observations of Tropospheric Reactive Nitrogen Species from the NASA Atmospheric Tomography Mission, AGU Fall Meeting Abstracts, 14, available at: http://adsabs.harvard.edu/abs/2017AGUFM.A14D02T (last access: 16 March 2020), 2017.

Thouret, V., Marenco, A., Logan, J. A., Nédélec, P., and Grouhel, C.: Comparisons of ozone measurements from the MOZAIC airborne program and the ozone sounding network at eight locations, J. Geophys. Res.-Atmos., 103, 25695-25720, https://doi.org/10.1029/98JD02243, 1998.

Tilmes, S., Lamarque, J.-F., Emmons, L. K., Conley, A., Schultz, M. G., Saunois, M., Thouret, V., Thompson, A. M., Oltmans, S. J., Johnson, B., and Tarasick, D.: Technical Note: Ozonesonde climatology between 1995 and 2011: description, evaluation and applications, Atmos. Chem. Phys., 12, 74757497, https://doi.org/10.5194/acp-12-7475-2012, 2012.

Trickl, T., Cooper, O. R., Eisele, H., James, P., Mücke, R., and Stohl, A.: Intercontinental transport and its influence on the ozone concentrations over central Europe: Three case studies, J. Geophys. Res.-Atmos., 108, 8530, https://doi.org/10.1029/2002JD002735, 2003.

Wespes, C., Hurtmans D., Clerbaux C., and Coheur P.-F.: $\mathrm{O}_{3}$ variability in the troposphere as observed by IASI over 2008-2016: Contribution of atmospheric chemistry and dynamics, J. Geophys. Res.-Atmos., 122, 2429-2451, https://doi.org/10.1002/2016JD025875, 2017.

Williams, J. E., Scheele, M. P., van Velthoven, P. F. J., Thouret, V., Saunois, M., Reeves, C. E., and Cammas, J.-P.: The influence of biomass burning and transport on tropospheric composition over the tropical Atlantic Ocean and Equatorial Africa during the West African monsoon in 2006, Atmos. Chem. Phys., 10, 9797-9817, https://doi.org/10.5194/acp-10-9797-2010, 2010.

Witte, J. C., Thompson, A. M., Smit, H. G. J., Vömel, H., Posny, F., and Stübi, R.: First Reprocessing of Southern Hemisphere ADditional OZonesondes Profile Records: 3. Uncertainty in Ozone Profile and Total Column, J. Geophys. Res.-Atmos., 123, 32433268, https://doi.org/10.1002/2017JD027791, 2018.

Wofsy, S. C.: HIAPER Pole-to-Pole Observations (HIPPO): finegrained, global-scale measurements of climatically important atmospheric gases and aerosols, Philos. T. R. Soc. A, 369, 20732086, https://doi.org/10.1098/rsta.2010.0313, 2011.

Wofsy, S. C., Daube, B. C., Jimenez, R., Kort, E., Pittman, J. V., Park, S., Commane, R., Xiang, B., Santoni, G., Jacob, D., Fisher, J., Pickett-Heaps, C., Wang, H., Wecht, K., Wang, Q.-Q., Stephens, B. B., Shertz, S., Watt, A. S., Romashkin, P., Campos, T., Haggerty, J., Cooper, W. A., Rogers, D., Beaton, S., Hendershot, R., Elkins, J. W., Fahey, D. W., Gao, R. S., Moore, F., Montzka, S. A., Schwarz, J. P., Perring, A. E., Hurst, D., Miller, B. R., Sweeney, C., Oltmans, S., Nance, D., Hintsa, E., Dutton, G., Watts, L. A., Spackman, J. R., Rosenlof, K. H., Ray, E. A., Hall, B., Zondlo, M. A., Diao, M., Keeling, R., Bent, J., Atlas, E. L., Lueb, R., and Mahoney, M. J.: HIPPO Merged 10-second Meteorology, Atmospheric Chemistry, and Aerosol Data. https://doi.org/10.3334/CDIAC/HIPPO_010 (CDIAC Release 20121129/ NCAR EOL Version 1.0), 2017.

Wofsy, S. C., Afshar, S., Allen, H. M., Apel, E., Asher, E. C., Barletta, B., Bent, J., Bian, H., Biggs, B. C., Blake, D. R., Blake, N., Bourgeois, I., Brock, C. A., Brune, W. H., Budney, J. W., Bui, T. P., Butler, A., Campuzano-Jost, P., Chang, C. S., Chin, M., Commane, R., Correa, G., Crounse, J. D., Cullis, P. D., Daube, B. C., Day, D. A., Dean-Day, J. M., Dibb, J. E., DiGangi, J. P., Diskin, G. S., Dollner, M., Elkins, J. W., Erdesz, F., Fiore, A. M., Flynn, C. M., Froyd, K., Gesler, D. W., Hall, S. R., Hanisco, T. F., Hannun, R. A., Hills, A. J., Hintsa, E. J., Hoffman, A., Hornbrook, R. S., Huey, L. G., Hughes, S., Jimenez, J. L., Johnson, B. J., Katich, J. M., Keeling, R. F., Kim, M. J., Kupc, A., Lait, L. R., Lamarque, J.-F., Liu, J., McKain, K., Mclaughlin, R. J., Meinardi, S., Miller, D. O., Montzka, S. A., Moore, F. L., Morgan, E. J., Murphy, D. M., Murray, L. T., Nault, B. A., Neuman, J. A., Newman, P. A., Nicely, J. M., Pan, X., Paplawsky, W., Peischl, J., Prather, M. J., Price, D. J., Ray, E., Reeves, J. M., Richardson, M., Rollins, A. W., Rosenlof, K. H., Ryerson, T. B., Scheuer, E., Schill, G. P., Schroder, J. C., Schwarz, J. P., St. Clair, J. M., Steenrod, S. D., Stephens, B. B., Strode, S. A., Sweeney, C., Tanner, D., Teng, A. P., Thames, A. B., Thompson, C. R., Ullmann, K., Veres, P. R., Vieznor, N., Wagner, N. L., Watt, A., Weber, R., Weinzierl, B., Wennberg, P., Williamson, C. J., Wilson, J. C., Wolfe, G. M., Woods, C. T., and Zeng, L. H.: ATom: Merged Atmospheric Chemistry, Trace Gases, and Aerosols, ORNL DAAC, Oak Ridge, Tennessee, USA, https://doi.org/10.3334/ORNLDAAC/1581, 2018.

Young, P. J., Archibald, A. T., Bowman, K. W., Lamarque, J.-F., Naik, V., Stevenson, D. S., Tilmes, S., Voulgarakis, A., Wild, O., 
Bergmann, D., Cameron-Smith, P., Cionni, I., Collins, W. J., Dalsøren, S. B., Doherty, R. M., Eyring, V., Faluvegi, G., Horowitz, L. W., Josse, B., Lee, Y. H., MacKenzie, I. A., Nagashima, T., Plummer, D. A., Righi, M., Rumbold, S. T., Skeie, R. B., Shindell, D. T., Strode, S. A., Sudo, K., Szopa, S., and Zeng, G.: Preindustrial to end 21st century projections of tropospheric ozone from the Atmospheric Chemistry and Climate Model Intercomparison Project (ACCMIP), Atmos. Chem. Phys., 13, 2063 2090, https://doi.org/10.5194/acp-13-2063-2013, 2013.

Young, P. J., Naik, V., Fiore, A. M., Gaudel, A., Guo, J., Lin, M. Y., Neu, J. L., Parrish, D. D., Rieder, H. E., Schnell, J. L., Tilmes, S., Wild, O., Zhang, L., Ziemke, J. R., Brandt, J., Delcloo, A., Doherty, R. M., Geels, C., Hegglin, M. I., Hu, L., Im, U., Kumar, R., Luhar, A., Murray, L., Plummer, D., Rodriguez, J., Saiz-Lopez, A., Schultz, M. G., Woodhouse, M. T., and Zeng, G.: Tropospheric Ozone Assessment Report: Assessment of global-scale model performance for global and regional ozone distributions, variability, and trends, Elem. Sci. Anth., 6, p. 10, https://doi.org/10.1525/elementa.265, 2018

Zbinden, R. M., Thouret, V., Ricaud, P., Carminati, F., Cammas, J.-P., and Nédélec, P.: Climatology of pure tropospheric profiles and column contents of ozone and carbon monoxide using MOZAIC in the mid-northern latitudes $\left(24^{\circ} \mathrm{N}\right.$ to $\left.50^{\circ} \mathrm{N}\right)$ from 1994 to 2009, Atmos. Chem. Phys., 13, 12363-12388, https://doi.org/10.5194/acp-13-12363-2013, 2013.

Zhang, B., Owen, R. C., Perlinger, J. A., Helmig, D., Martín, M. V., Kramer, L., Mazzoleni, L. R., and Mazzoleni, C.: Ten-year chemical signatures associated with long-range transport observed in the free troposphere over the central North Atlantic, Elem. Sci. Anth., 5, p. 8, https://doi.org/10.1525/elementa.194, 2017.
Zhang, L., Jacob, D. J., Boersma, K. F., Jaffe, D. A., Olson, J. R., Bowman, K. W., Worden, J. R., Thompson, A. M., Avery, M. A., Cohen, R. C., Dibb, J. E., Flock, F. M., Fuelberg, H. E., Huey, L. G., McMillan, W. W., Singh, H. B., and Weinheimer, A. J.: Transpacific transport of ozone pollution and the effect of recent Asian emission increases on air quality in North America: an integrated analysis using satellite, aircraft, ozonesonde, and surface observations, Atmos. Chem. Phys., 8, 6117-6136, https://doi.org/10.5194/acp-8-6117-2008, 2008.

Ziemke, J. R., Chandra S., and Bhartia P. K.: A 25-year data record of atmospheric ozone in the Pacific from Total Ozone Mapping Spectrometer (TOMS) cloud slicing: Implications for ozone trends in the stratosphere and troposphere, J. Geophys. Res.Atmos., 110, D15105, https://doi.org/10.1029/2004JD005687, 2005.

Ziemke, J. R., Chandra S., Duncan B. N., Froidevaux L., Bhartia P. K., Levelt P. F., and Waters J. W.: Tropospheric ozone determined from Aura OMI and MLS: Evaluation of measurements and comparison with the Global Modeling Initiative's Chemical Transport Model, J. Geophys. Res.-Atmos., 111, D19303, https://doi.org/10.1029/2006JD007089, 2006.

Ziemke, J. R., Strode, S. A., Douglass, A. R., Joiner, J., Vasilkov, A., Oman, L. D., Liu, J., Strahan, S. E., Bhartia, P. K., and Haffner, D. P.: A cloud-ozone data product from Aura OMI and MLS satellite measurements, Atmos. Meas. Tech., 10, 40674078, https://doi.org/10.5194/amt-10-4067-2017, 2017. 